\title{
A structural and catalytic model for zinc phosphoesterases $\dagger$
}

\author{
Rebecca R. Buchholz, ${ }^{a}$ Morgan E. Etienne, ${ }^{a}$ Anneke Dorgelo, ${ }^{a}$ Ruth E. Mirams, ${ }^{a}$ Sarah J. Smith, ${ }^{a}$ \\ Shiao Yun Chow, ${ }^{a}$ Lyall R. Hanton, ${ }^{b}$ Geoffrey B. Jameson, ${ }^{c}$ Gerhard Schenk ${ }^{a}$ and Lawrence R. Gahan $* a$
}

\author{
Received 24th April 2008, Accepted 4th August 2008 \\ First published as an Advance Article on the web 23rd September 2008 \\ DOI: $10.1039 / \mathrm{b806391e}$
}

A structural model for the active site of phosphoesterases, enzymes that degrade organophosphate neurotoxins, has been synthesised. The ligand [2-((2-hydroxy-3-(((2-hydroxyethyl)(pyridin-2ylmethyl)amino)methyl)-5-methylbenzyl)(pyridin-2-ylmethyl)amino)acetic acid] $\left(\mathrm{H}_{3} \mathrm{~L} 1\right)$ and two $\mathrm{Zn}(\mathrm{II})$ complexes have been prepared and characterised as $\left[\mathrm{Zn}_{2}(\mathrm{HL} 1)\left(\mathrm{CH}_{3} \mathrm{COO}\right)\right]\left(\mathrm{PF}_{6}\right) \cdot \mathrm{H}_{2} \mathrm{O}$ and $\mathrm{Li}\left[\mathrm{Zn}_{2}(\mathrm{HL} 1)\right]_{4}\left(\mathrm{PO}_{4}\right)_{2}\left(\mathrm{PF}_{6}\right)_{3} \cdot\left(\mathrm{CH}_{3} \mathrm{OH}\right)$. The ligand $\left(\mathrm{H}_{3} \mathrm{L1}\right)$ and complex $\left[\mathrm{Zn}_{2}(\mathrm{HL} 1)\left(\mathrm{CH}_{3} \mathrm{COO}\right)\right]\left(\mathrm{PF}_{6}\right) \cdot \mathrm{H}_{2} \mathrm{O}$ were characterised through ${ }^{1} \mathrm{H}$ NMR, ${ }^{13} \mathrm{C}$ NMR, mass spectroscopy and microanalysis. The X-ray crystal structure of $\mathrm{Li}\left[\mathrm{Zn}_{2}(\mathrm{HL} 1)\right]_{4}\left(\mathrm{PO}_{4}\right)_{2}\left(\mathrm{PF}_{6}\right)_{3} \cdot\left(\mathrm{CH}_{3} \mathrm{OH}\right)$ revealed a tetramer of dinuclear complexes, bridged by two phosphate molecules and bifurcating acetic acid arms. Functional studies of the zinc complex with the substrate bis(4-nitrophenyl)phosphate (bNPP) determined the complex with $\mathrm{HL}^{2-}$ to be a competent catalyst with $k_{\text {cat }}=1.26 \pm 0.06 \times 10^{-6} \mathrm{~s}^{-1}$.

\section{Introduction}

Phosphoesterases hydrolyse the phosphorus oxygen bond of tri-, di- or monophosphoesters. ${ }^{1-4}$ Among them, triesterases are enzymes that have acquired the ability to degrade a range of synthetic organophosphates (OP) including chemical warfare agents such as sarin and VX, and insecticides such as paraoxon. ${ }^{5,6}$ The members of this group of enzymes have been isolated and characterised from Pseudomonas diminuta, Flavobacterium sp. and Agrobacterium radiobacter..$^{7-10}$ The binuclear glycerophosphodiesterase from Enterobacter aerogenes $(\mathrm{GpdQ})^{11,12}$ is structurally unrelated to these triesterases but also has modest activity towards OPs and diester products of VX degradation. ${ }^{4}$ Importantly, recombinant Escherichia coli co-expressing the triesterase from A. radiobacter (OpdA) and $\mathrm{GpdQ}$ is able to survive under conditions where OPs are the only source of phosphate. ${ }^{12}$ Thus, this bacterial system may be sufficiently robust to find an application in the bioremediation of, for example, water supplies that are contaminated with pesticide wastes. ${ }^{12}$

The in vivo metal ion compositions of metalloenzymes are often diverse. Anomalous scattering analysis of OpdA has indicated that its likely metal ion composition is of the Fe(II)-Zn(II) type, whereas GpdQ is speculated to be of the di-Fe(II) type. ${ }^{13,14}$ However, the catalytic activity may be regenerated from the apo-forms of both enzymes upon addition of various divalent metals, including $\mathrm{Mn}(\mathrm{II}), \mathrm{Co}(\mathrm{II}), \mathrm{Cd}(\mathrm{II})$ and $\mathrm{Zn}$ (II). ${ }^{11,14,15}$ The highest hydrolytic activity for the OP-degrading hydrolase from

${ }^{a}$ School of Molecular and Microbial Sciences, The University of Queensland, Queensland, Australia 4072.E-mail: gahan@uq.edu.au

${ }^{b}$ Department of Chemistry, Te Tari Hua-Ruanuku, University of Otago, PO Box 56, Dunedin, New Zealand

'Massey University, Palmerston North Campus, Private Bag 11222, Palmerston North, 5301, New Zealand

$\dagger$ Electronic supplementary information (ESI) available: TOF MS data. CCDC reference number 686253. For ESI and crystallographic data in CIF or other electronic format see DOI: $10.1039 / \mathrm{b} 806391 \mathrm{e}$
P. diminuta $(\mathrm{OPH}), \mathrm{OpdA}$ and GpdQ has been recorded with Co(II). ${ }^{13,15,16}$

OPH and OpdA have high structural similarity and sequence homology ( $-90 \%$ identity), and are assumed to have a similar mechanism of action..$^{9,10,17}$ The active sites of these enzymes provide essentially the same N,O asymmetric coordination environment for the two divalent metal ions (Fig. 1). The metal ions are coordinated by nitrogen donors located on four histidine ligands, an aspartate, a carboxylated lysine, and a metal ion-bridging hydroxide ion. ${ }^{9,16,18-20}$ In GpdQ, the more buried $\alpha$-metal is coordinated in a distorted trigonal-bipyramidal arrangement by the donor atoms from His197, His10, Asp8, the bridging Asp50 and hydroxide, whilst the more solvent exposed $\beta$-metal is ligated by His156, His195, Asn80 and the two bridging donors. ${ }^{13}$

Both kinetic studies and kinetic isotope $\left({ }^{18} \mathrm{O}\right)$ effect studies have determined that the hydrolysis of the $\mathrm{P}-\mathrm{O}$ bond of OPs by phosphotriesterases is accompanied by an inversion of configuration at the phosphorus atom. ${ }^{21}$ While this general mechanism is widely accepted, some details such as the identity of the attacking nucleophile remain subject to debate, with possibilities including the bridging hydroxo, a terminal hydroxo or activated uncoordinated water. ${ }^{13,17-22}$ While a mechanism involving the bridging hydroxide was initially favoured, an alternative model has gained credence, whereby a hydroxide that is terminally bound to the $\alpha$-metal ion attacks the phosphorus centre of the substrate, which is monodentately bound to the $\beta$-metal ion. ${ }^{20}$

Biomimetics are useful for a number of reasons, including that it is often easier to study structural and mechanistic features of complex biological systems using a smaller and simpler model system. ${ }^{3,23-27}$ Models may be structural, electronic and/or functional mimics, although lower catalytic activity is to be expected from the model complexes as they tend to be poor functional mimics in comparison with their corresponding enzyme systems. ${ }^{28-34}$ This approach is exemplified by recent investigations into the structure and function of the binuclear mono and diesterase purple acid phosphatase..$^{27,31,33,35}$ We report 


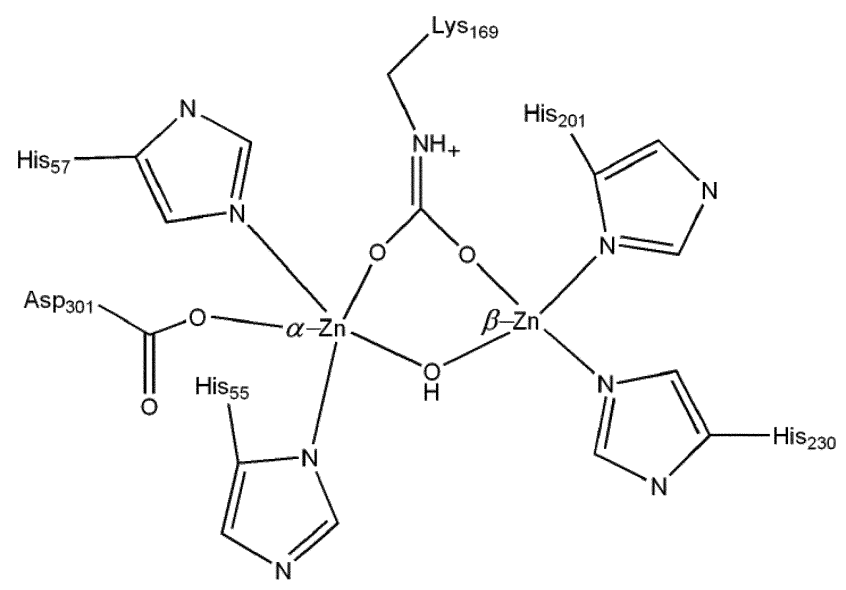

(a) $\mathrm{OPH}$

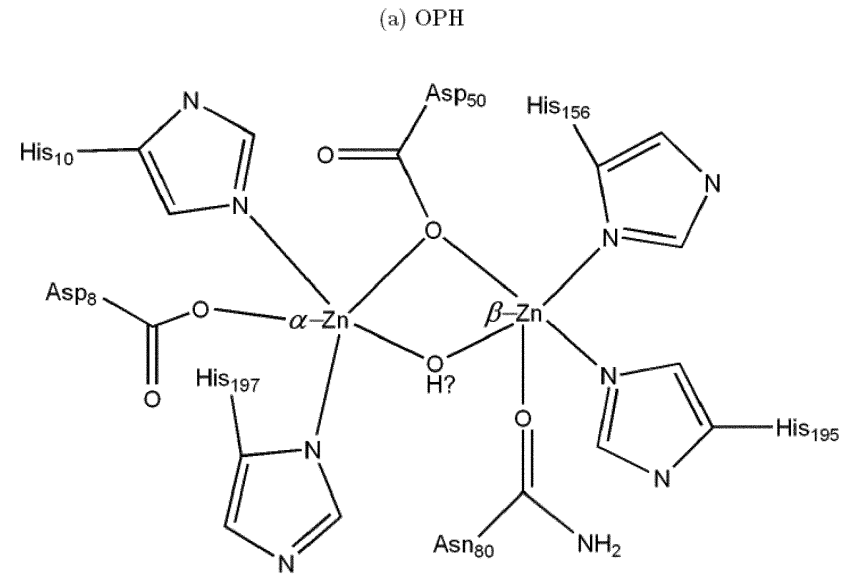

(b) GpdQ

Fig. 1 Schematic of the active sites of $\mathrm{OPH}^{25}$ and $\mathrm{GpdQ}^{13}$

herein, the synthesis and characterisation of [2-((2-hydroxy3-(((2-hydroxyethyl)(pyridin-2-ylmethyl)amino)methyl)5-methylbenzyl)(pyridin-2-yl-methyl)amino)acetic acid] $\left(\mathrm{H}_{3} \mathrm{~L} 1\right)$ (Fig. 2) and its di-Zn(II) complex, specifically as a structural model for the GpdQ enzyme. The complex has been characterised spectroscopically, and its catalytic properties were investigated using the substrate bis(4-nitrophenyl) phosphate (bNPP). In addition, an octanuclear zinc(II) complex of $\mathrm{HL}^{2-}$ has been characterised by $\mathrm{X}$-ray crystallography.

\section{Results and discussion}

\section{Synthesis of the ligand and complex}

The ethyl ester $\mathrm{H}_{2} \mathrm{EtL} 1$ was produced in a reaction sequence (Scheme 1) involving a statistical reaction between $N$-(2-pyridylmethyl)glycine ethyl ester, ${ }^{36} \quad N$-(2-pyridylmethyl)-2-aminoethanol $^{37}$ and 2,6-bis(chloromethyl)-4-methyl-phenol ${ }^{38}$ in tetrahydrofuran in the presence of base. Chromatographic separation of the mixture with silica readily produced ethyl 2-((2-hydroxy3-(((2-hydroxyethyl)(pyridin-2-ylmethyl)amino)methyl)-5-methylbenzyl)(pyridin-2-ylmethyl)amino)acetate $\left(\mathrm{H}_{2}\right.$ EtL1) as well as the symmetrical analogues [diethyl 2,20-(2-hydroxy-5-methyl-1,3phenylene)bis(methylene)bis((pyridin - 2 -ylmethyl)azanediyl)dia cetate $]$ and the previously reported ligand 2,6-bis([(2-pyridy-

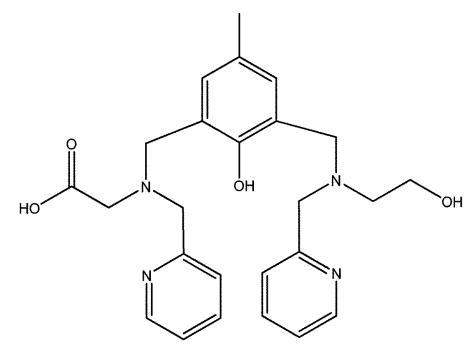

[2-((2-hydroxy-3-(((2-hydroxyethyl)(pyridin-2-ylmethyl)amino)methyl)5methylbenzyl)(pyridin-2-yl-methyl)amino)acetic acid] $\left(\mathrm{H}_{3} \mathrm{~L} 1\right)$

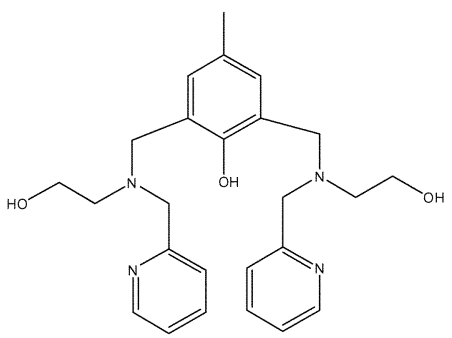

2,6-bis([(2-pyridylmethyl)(2-hydroxyethyl)amino]methyl)4-methylphenol $\left(\mathrm{H}_{3} \mathrm{~L} 2\right)^{28}$

Fig. $2 \mathrm{H}_{3} \mathrm{~L} 1$ and $\mathrm{H}_{3} \mathrm{~L} 2$.

lmethyl)(2-hydroxyethyl)amino]methyl)-4-methylphenol $\left(\mathrm{H}_{3} \mathrm{~L} 2\right)$ (Fig. 2) ${ }^{28}$ The reaction of $\mathrm{H}_{2} \mathrm{EtL} 1$ with lithium hydroxide resulted in a lithium salt of [2-((2-hydroxy-3-(((2-hydroxyethyl)(pyridin2-ylmethyl)amino)methyl)-5-methylbenzyl)(pyridin-2-ylmethyl)amino)acetic acid] $\left(\mathrm{LiH}_{2} \mathrm{~L} 1\right){ }^{39}$

The nomenclature employed for the ligand refers to the number of protons possibly available for removal upon complexation. Thus, for $\mathrm{H}_{3} \mathrm{~L} 1$, the inference is that the protons on the phenoxide, the carboxylate and the pendant alcohol are candidates for deprotonation. Possible protonation sites on the pyridine nitrogen atoms are not included in this nomenclature but these are considered in the determination of the ligand $\mathrm{p} K_{\mathrm{a}}$ values (vide infra).

The reaction of $\mathrm{LiH}_{2} \mathrm{~L} 1$ with zinc acetate in the presence of sodium hexafluorophosphate resulted in a white solid, for which microanalytical and spectroscopic data support the assignment as $\left[\mathrm{Zn}_{2}(\mathrm{HL} 1)\left(\mathrm{CH}_{3} \mathrm{COO}\right)\right]\left(\mathrm{PF}_{6}\right) \cdot \mathrm{H}_{2} \mathrm{O}$. The crystal produced for the $\mathrm{X}$ ray structural study was isolated from the bulk reaction mixture upon standing with sodium hexafluorophosphate. Subsequent structural analysis indicated a complex structure (vide infra) most likely resulting from the crystallisation methodology and not necessarily representative of the initial product produced in the reaction. The structure of this complex represents its only form of characterization and is reported because of its high nuclearity and some of its structural features.

\section{Solid state structure}

The complex $\mathrm{Li}\left[\mathrm{Zn}_{2}(\mathrm{HL} 1)\right]_{4}\left(\mathrm{PO}_{4}\right)_{2}\left(\mathrm{PF}_{6}\right)_{3} \cdot\left(\mathrm{CH}_{3} \mathrm{OH}\right)$ crystallised as a tetramer of dinuclear $\left[\mathrm{Zn}_{2}(\mathrm{HL} 1)\right]^{2+}$ units with two $\mathrm{PO}_{4}{ }^{3-}$ molecules, one lithium ion and a molecule of methanol within the complex cation. Diagrams of the complex cation are shown in Fig. 3 and Fig. 4 with the crystal data listed in Table 1 with important bond distances and angles listed in Table 2 (listed bond lengths and angles involving disordered atoms refer to the main residue, i.e. the higher occupancy). The two $\mathrm{PO}_{4}{ }^{3-}$ anions are 


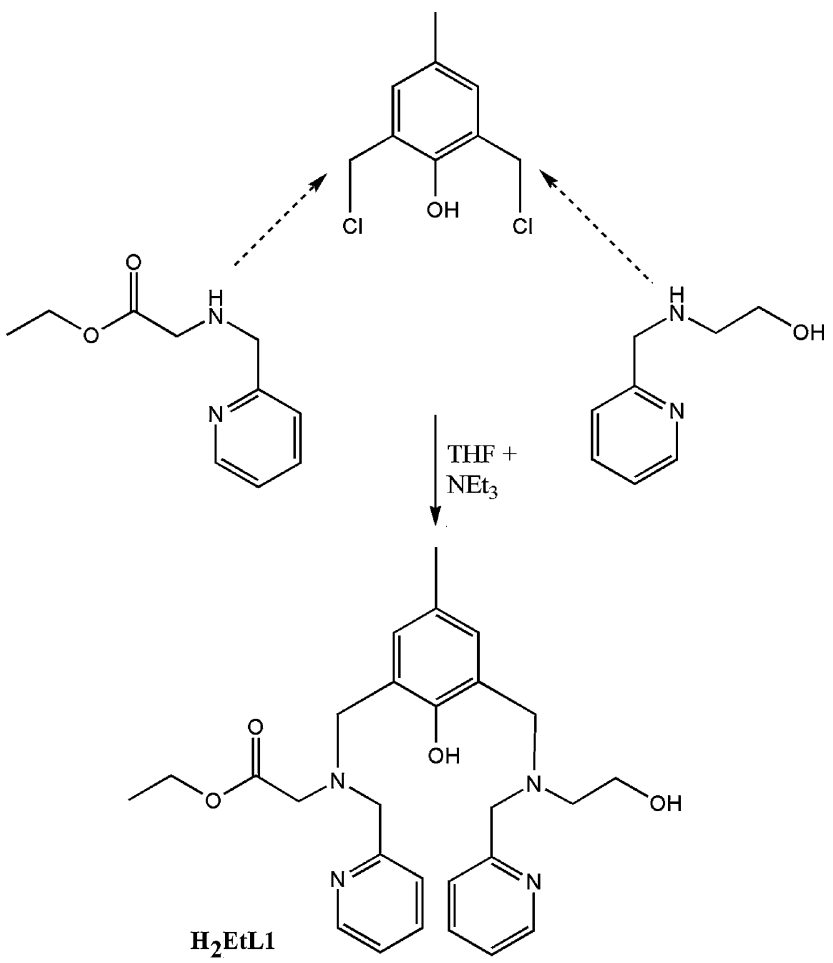

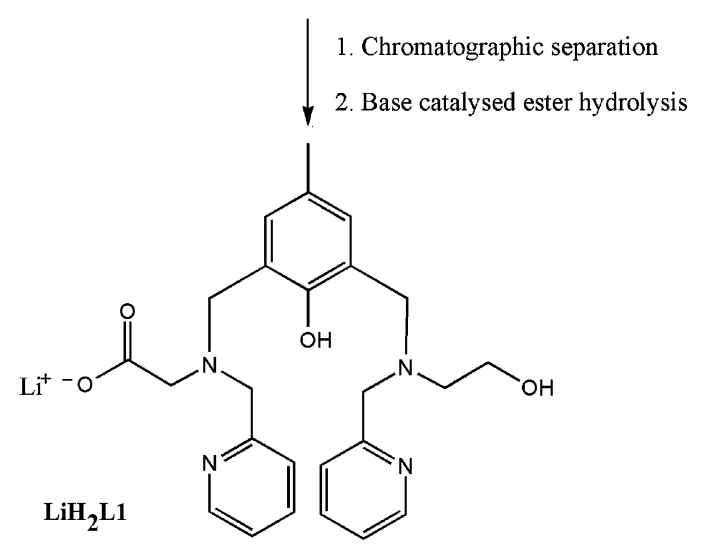

Scheme 1 Synthesis of ethyl-2-((2-hydroxy-3-(((2-hydroxyethyl)(pyridin2-ylmethyl)amino)methyl)-5-methylbenzyl)(pyridin-2-ylmethyl)amino)acetate $\left(\mathrm{H}_{2}\right.$ EtL1) and the lithium salt $\left(\mathrm{LiH}_{2} \mathrm{Ll}\right)$

each connected to four $\mathrm{Zn}$ (II) ions. Three $\mathrm{PF}_{6}{ }^{-}$anions, two of them disordered, complete the structure. A significant disorder was also observed in many of the ligand's aromatic rings. The electron density, apparent in the centre of the tetrameric structure, was assigned to a lithium ion most likely arising from the use of the lithium salt of the ligand in the synthetic step; the isotropic atomic displacement parameters suggested that either a sodium or a hydrogen ion was inappropriate. The lithium is strongly associated with the oxygen of the $\mathrm{PO}_{4}{ }^{3-}$ anions (1.95-2.06 $⿱$ ) and with the oxygen atom of a solvent methanol molecule ( $2.43 \AA$ ). Although no $\mathrm{PO}_{4}{ }^{3-}$ was intentionally added to the crystallising mixture, possible sources include an impurity in the sodium hexafluorophosphate, or from hydrolysis of $\mathrm{PF}_{6}{ }^{-}$to $\mathrm{PO}_{4}{ }^{3-}$ by the $\mathrm{Zn}$ (II) complex. ${ }^{40}$ The bond lengths and angles, as well as the coordinative saturation, of this moiety support its assignment as $\mathrm{PO}_{4}{ }^{3-}$ as opposed to $\mathrm{PO}_{2} \mathrm{~F}_{2}^{-}$, another hydrolytic product of
Table 1 Crystallographic data for $\mathrm{Li}\left[\mathrm{Zn}_{2}(\mathrm{HL} 1)\right]_{4}\left(\mathrm{PO}_{4}\right)_{2}\left(\mathrm{PF}_{6}\right)_{3} \cdot\left(\mathrm{CH}_{3} \mathrm{OH}\right)$

\begin{tabular}{|c|c|}
\hline Empirical formula & $\mathrm{C}_{101} \mathrm{H}_{116} \mathrm{~F}_{18} \mathrm{LiN}_{16} \mathrm{O}_{25} \mathrm{P}_{5} \mathrm{Zn}_{8}$ \\
\hline Formula weight & 2980.85 \\
\hline Temperature/K & $90(2)$ \\
\hline Wavelength/Å & 0.71073 \\
\hline Crystal system & Monoclinic \\
\hline Space group & $P 2_{1} / c$ \\
\hline$a / \AA$ & $16.560(3)$ \\
\hline$b / \AA$ & $40.130(2)$ \\
\hline$c / \AA ̊$ & $19.710(3)$ \\
\hline$\beta /^{\circ}$ & $104.92(2)$ \\
\hline$V / \AA^{3}$ & $12657(3)$ \\
\hline$Z$ & 4 \\
\hline Absorption coefficient $/ \mathrm{mm}^{-1}$ & 1.650 \\
\hline$D_{\text {calcd }} / \mathrm{Mg} \mathrm{m}^{-3}$ & 1.564 \\
\hline Reflections collected/unique & $80413 / 19659\left(R_{\mathrm{int}}=0.0414\right)$ \\
\hline Data/restraints/parameters & $19659 / 4700 / 2352$ \\
\hline Final $R$ indices $[I>2 \sigma(I)]$ & $R=0.0994, \mathrm{w} R_{2}=0.2348$ \\
\hline$R$ indices (all data) & $R=0.1195, \mathrm{w} R_{2}=0.2491$ \\
\hline
\end{tabular}

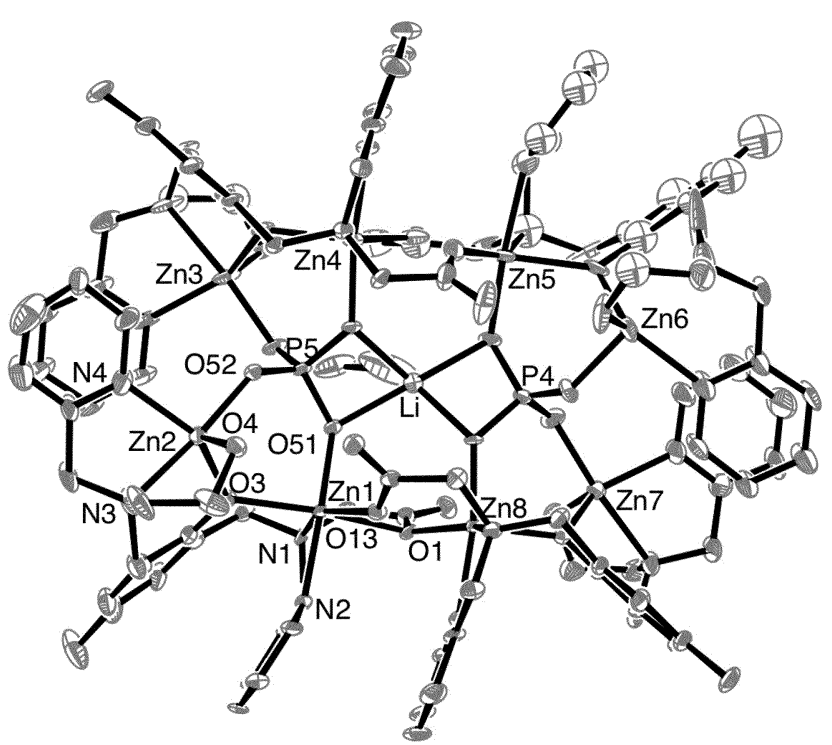

Fig. 3 ORTEP plot of the main residue of the disordered complex cation of $\mathrm{Li}\left[\mathrm{Zn}_{2}(\mathrm{HL} 1)\right]_{4}\left(\mathrm{PO}_{4}\right)_{2}\left(\mathrm{PF}_{6}\right)_{3} \cdot\left(\mathrm{CH}_{3} \mathrm{OH}\right)$. Thermal probability ellipsoids are drawn at the $50 \%$ probability level. Hydrogen atoms are omitted for clarity.

$\mathrm{PF}_{6}{ }^{-}{ }^{41}$ In $\mathrm{PO}_{2} \mathrm{~F}_{2}{ }^{-}$, the $\mathrm{P}-\mathrm{F}$ and $\mathrm{P}-\mathrm{O}$ bond lengths are different (P-F, 1.49-1.55 $\AA$; P-O, 1.43-1.47 $)^{42-44}$ whereas in the present structure there is no difference between the two sets of bonds of the tetrahedral anions (1.509-1.541 $\mathrm{\AA}$ ). The charge balance also supports the presence of $\mathrm{PO}_{4}{ }^{3-}$ rather than $\mathrm{PO}_{2} \mathrm{~F}_{2}{ }^{-}$.

There are four six-coordinate $(\mathrm{Zn}(1), \mathrm{Zn}(4), \mathrm{Zn}(5)$ and $\mathrm{Zn}(8))$ and four five-coordinate zinc centres $(\mathrm{Zn}(2), \mathrm{Zn}(3), \mathrm{Zn}(6)$ and $\mathrm{Zn}(7))$ in the complex cation. The molecule is composed of two halves, each composed of two $\mathrm{HL}^{2-}$ ligands coordinated to four $\mathrm{Zn}$ (II) ions. The halves are connected by the two $\mathrm{PO}_{4}{ }^{3-}$ anions, separating the zinc atoms by approximately $4.72 \AA$, and forming a zipper-like connection with the $\mathrm{Li}^{+}$cation in the centre of the structure, but not present on a symmetry element. One side of the zipper is composed of $\mathrm{Zn}(7), \mathrm{Zn}(8), \mathrm{Zn}(1)$, and $\mathrm{Zn}(2)$, the other $\mathrm{Zn}(6), \mathrm{Zn}(5), \mathrm{Zn}(4)$ and $\mathrm{Zn}(3)$. The five-coordinate $\mathrm{Zn}$ (II) centres $(\mathrm{Zn}(2), \mathrm{Zn}(3), \mathrm{Zn}(6)$ and $\mathrm{Zn}(7))$ are at the end of the respective zippers. The average $\mathrm{Zn}-\mathrm{Zn}$ distance in the dinuclear complexes is $3.55 \AA$. $\mathrm{Zn}(1)$ and $\mathrm{Zn}(2)$ share a coordination environment 
Table 2 Selected bond lengths $(\AA)$ and angles $\left({ }^{\circ}\right)$ for the main residue of the disordered complex Li[ $\left.\mathrm{Zn}_{2}(\mathrm{HL})\right]_{4}\left(\mathrm{PO}_{4}\right)_{2}\left(\mathrm{PF}_{6}\right)_{3} \cdot\left(\mathrm{CH}_{3} \mathrm{OH}\right)$

Molecule 1

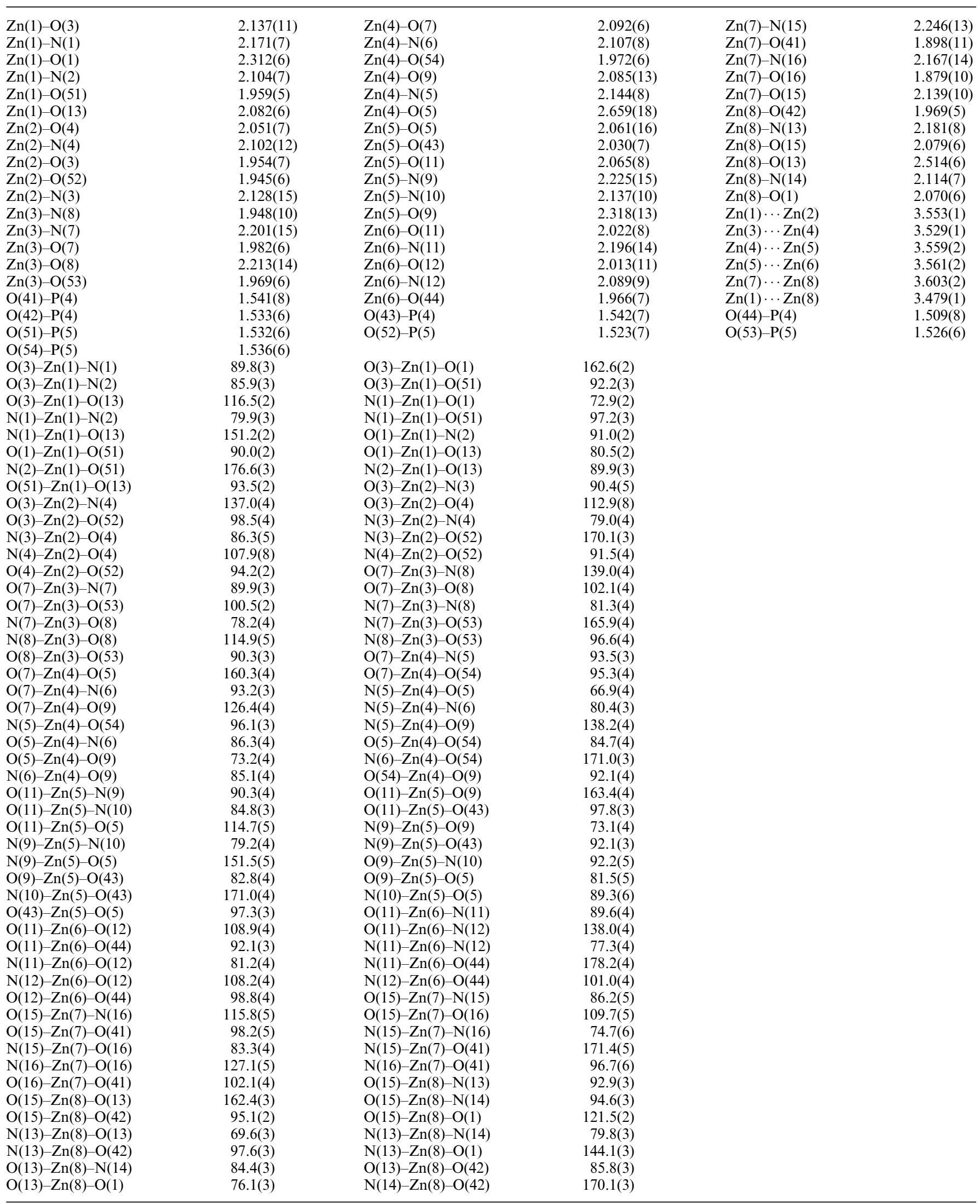


Table 2 (Contd.)

\begin{tabular}{lclr}
\hline Molecule 1 & & \\
\hline $\mathrm{N}(14)-\mathrm{Zn}(8)-\mathrm{O}(1)$ & $87.0(2)$ & $\mathrm{O}(42)-\mathrm{Zn}(8)-\mathrm{O}(1)$ & $89.8(2)$ \\
$\mathrm{Zn}(1)-\mathrm{O}(3)-\mathrm{Zn}(2)$ & $120.5(6)$ & $\mathrm{Zn}(4)-\mathrm{O}(7)-\mathrm{Zn}(3)$ & $120.0(3)$ \\
$\mathrm{Zn}(5)-\mathrm{O}(11)-\mathrm{Zn}(6)$ & $121.2(4)$ & $\mathrm{Zn}(8)-\mathrm{O}(15)-\mathrm{Zn}(7)$ & $117.3(4)$ \\
$\mathrm{Zn}(1)-\mathrm{O}(1)-\mathrm{Zn}(8)$ & $105.0(2)$ & $\mathrm{Zn}(4)-\mathrm{O}(5)-\mathrm{Zn}(5)$ & $97.0(3)$ \\
$\mathrm{Zn}(5)-\mathrm{O}(9)-\mathrm{Zn}(4)$ & $107.7(5)$ & $\mathrm{Zn}(8)-\mathrm{O}(13)-\mathrm{Zn}(1)$ & $98.0(3)$ \\
$\mathrm{O}(44)-\mathrm{P}(4)-\mathrm{O}(42)$ & $110.3(4)$ & $\mathrm{O}(44)-\mathrm{P}(4)-\mathrm{O}(41)$ & $111.1(5)$ \\
$\mathrm{O}(42)-\mathrm{P}(4)-\mathrm{O}(41)$ & $109.8(4)$ & $\mathrm{O}(44)-\mathrm{P}(40-\mathrm{O}(43)$ & $114.6(4)$ \\
$\mathrm{O}(42)-\mathrm{P}(4)-\mathrm{O}(43)$ & $102.9(4)$ & $\mathrm{O}(41)-\mathrm{P}(4)-\mathrm{O}(43)$ & $107.7(4)$ \\
$\mathrm{O}(52)-\mathrm{P}(5)-\mathrm{O}(53)$ & $110.0(4)$ & $\mathrm{O}(52)-\mathrm{P}(5)-\mathrm{O}(51)$ & $114.4(4)$ \\
$\mathrm{O}(53)-\mathrm{P}(5)-\mathrm{O}(51)$ & $108.6(4)$ & $\mathrm{O}(52)-\mathrm{P}(5)-\mathrm{O}(54)$ & $103.6(3)$ \\
$\mathrm{O}(53)-\mathrm{P}(5)-\mathrm{O}(54)$ & $109.5(4)$ & $\mathrm{O}(51)-\mathrm{P}(5)-\mathrm{O}(54)$ & $2.538(17)$ \\
\hline $\mathrm{Hydrogen}$ bonding & & & $2.598(18)$ \\
\hline $\mathrm{O}(2) \cdots \mathrm{O}(16)$ & & & 163.1 \\
$\mathrm{O}(10) \cdots \mathrm{O}(8)$ & $2.574(10)$ & $\mathrm{O}(6) \cdots \mathrm{O}(12)$ & 177.1 \\
$\mathrm{O}(2) \cdots \mathrm{H}-\mathrm{O}(16)$ & $2.57(2)$ & $\mathrm{O}(14) \cdots \mathrm{O}(4)$ & $\mathrm{O}(6) \cdots \mathrm{H}-\mathrm{O}(12)$ \\
$\mathrm{O}(10) \cdots \mathrm{H}-\mathrm{O}(8)$ & 165.4 & $\mathrm{O}(14) \cdots \mathrm{H}-\mathrm{O}(4)$ & \\
\hline
\end{tabular}

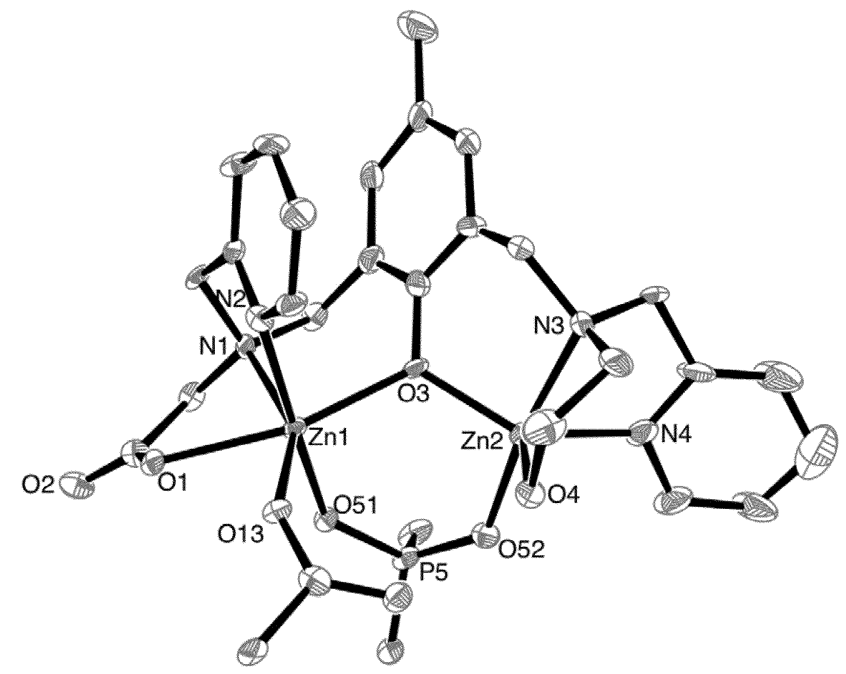

Fig. 4 ORTEP plot of a fragment of the complex cation of $\mathrm{Li}\left[\mathrm{Zn}_{2}(\mathrm{HL})\right]_{4}\left(\mathrm{PO}_{4}\right)_{2}\left(\mathrm{PF}_{6}\right)_{3} \cdot\left(\mathrm{CH}_{3} \mathrm{OH}\right)$. Thermal probability ellipsoids are drawn at the $50 \%$ probability level. Hydrogen atoms are omitted for clarity.

of an $\mathrm{HL}_{1}{ }^{2-}$ ligand with an unsymmetrical bridge through the $\mu$-phenoxo oxygen donor $\mathrm{O}(3)$; likewise, $\mathrm{Zn}(3)$ and $\mathrm{Zn}(4), \mathrm{Zn}(5)$ and $\mathrm{Zn}(6)$, and $\mathrm{Zn}(7)$ and $\mathrm{Zn}(8)$ each share an $\mathrm{HL}^{2-}$ ligand. The six-coordinate geometry of $\mathrm{Zn}(1)$ and $\mathrm{Zn}(8)$ (and by analogy $\mathrm{Zn}(4)$ and $\mathrm{Zn}(5))$ is made up of bonds to the $\mu$-phenoxide $(\mathrm{Zn}(1)-\mathrm{O}(3))$, the pyridine nitrogen $(\mathrm{Zn}(1)-\mathrm{N}(2))$, the tertiary nitrogen $(\mathrm{Zn}(1)-$ $\mathrm{N}(1))$, the $\mathrm{PO}_{4}{ }^{3-}$ oxygen $(\mathrm{Zn}(1)-\mathrm{O}(51))$, the oxygen of an adjacent carboxylate $(\mathrm{Zn}(1)-\mathrm{O}(13))$ and the oxygen of the carboxylate from the $\mathrm{HL1}^{2-}$ shared with $\mathrm{Zn}(8)(\mathrm{Zn}(1)-\mathrm{O}(1))$. Thus, $\mathrm{Zn}(1)$ and $\mathrm{Zn}(8)$ (and similarly $\mathrm{Zn}(4)$ and $\mathrm{Zn}(5)$ ) are bridged through a bifurcation of the oxygen donors of the acetic acid arms of the HL1 ${ }^{2-}$ ligand, one oxygen from each ligand. In each case, two of the interactions are relatively long $(\mathrm{Zn}(1)-\mathrm{O}(1), \mathrm{Zn}(8)-\mathrm{O}(13), \mathrm{Zn}(4)-\mathrm{O}(5), \mathrm{Zn}(5)-$ $\mathrm{O}(9))$ whereas the others are significantly shorter $(\mathrm{Zn}(1)-\mathrm{O}(13)$, $\mathrm{Zn}(8)-\mathrm{O}(1), \mathrm{Zn}(4)-\mathrm{O}(9), \mathrm{Zn}(5)-\mathrm{O}(5))$. The $\mathrm{Zn}(4)$ and $\mathrm{Zn}(8)$ sites, which have the long ( $>2.5 \AA$ ) $\mathrm{Zn}-\mathrm{O}$ (carboxylate) bonds, are noticeably more distorted from the octahedral geometry, and in fact may be better described as edge-bridged trigonal-bipyramidal structures. The bifurcated nature of this interaction is reminiscent of that seen for $\mathrm{Asp}_{50}$ in the structure of GpdQ. ${ }^{13}$

The five-coordinate $\mathrm{Zn}(2)$ (and by analogy $\mathrm{Zn}(3), \mathrm{Zn}(6)$ and $\mathrm{Zn}(7))$ ions are trigonal-bipyramidal, where the amine nitrogen and phosphate oxygen atoms are trans. The five-coordinate geometry is comprised of bonds to the bridging phenoxide ( $\mathrm{Zn}(2)$ $\mathrm{O}(3))$, a pyridine nitrogen $(\mathrm{Zn}(2)-\mathrm{N}(4)$, a tertiary nitrogen $(\mathrm{Zn}(2)-$ $\mathrm{N}(3)$ ), a hydroxyl oxygen $(\mathrm{Zn}(2)-\mathrm{O}(4))$ and a phosphate oxygen $(\mathrm{Zn}(2)-\mathrm{O}(52))$. Strong hydrogen bonds link the hydroxyl oxygen of one $\mathrm{Zn}_{2} \mathrm{HL} 1$ unit to the uncoordinated carboxylate oxygen of a neighbouring $\mathrm{Zn}_{2} \mathrm{HL} 1$ unit (for example: $\mathrm{O}(4)-\mathrm{H} \cdots \mathrm{O}(14)$ 2.597(4) $\AA$, O(4)-H . . O(14) $177^{\circ}$ ).

\section{Mass spectrometry}

The ligand precursor $\mathrm{H}_{2}$ EtL1 displays the expected low-resolution positive-ion mass spectrum with $m / z$ 479.21. The ESI-MS of the zinc complex with the $\mathrm{HL1}^{2-}$ ligand, characterised as $\left[\mathrm{Zn}_{2}(\mathrm{HL} 1)\left(\mathrm{CH}_{3} \mathrm{COO}\right)\right]\left(\mathrm{PF}_{6}\right)$ in acetonitrile indicates the presence of $\left[\mathrm{Zn}_{2}(\mathrm{HL} 1)(\mathrm{CHOO})\right]^{+}(\mathrm{m} / z$ 625.06, 623.06 and 621.06), $\left[\mathrm{Zn}_{2}(\mathrm{HL} 1)\right]^{+}(m / z 579.06,577.06$ and 575.06) with the most prominent peaks typical of the isotopic pattern expected for a di$\mathrm{Zn}$ (II) complex. In addition, the species $[\mathrm{Zn}(\mathrm{HL} 1)]^{+}(\mathrm{m} / \mathrm{z} 517.14$, 515.14 and 513.14) was also present. The ESI-MS in wateracetonitrile $(90: 10)$ indicates the presence of $[\mathrm{Zn}(\mathrm{HL} 1)+\mathrm{H}]^{+}$ $(\mathrm{m} / z$ 513.14) with an isotope pattern consistent with the presence of only one metal ion. In the presence of two equivalents of zinc acetate, in the same solvent mixture, peaks attributed to $\left[\mathrm{Zn}(\mathrm{HL} 1)\left(\mathrm{CH}_{3} \mathrm{COO}\right)\left(\mathrm{H}_{2} \mathrm{O}\right)_{6}+2 \mathrm{H}\right]^{+}(\mathrm{m} / \mathrm{z} 681.23,682.23$ and $683.23)$ and $\left[\mathrm{Zn}_{2}(\mathrm{HL} 1)\left(\mathrm{CH}_{3} \mathrm{COO}\right)\left(\mathrm{H}_{2} \mathrm{O}\right)_{6}\right]^{+}(\mathrm{m} / z$ 743.14, 745.14, 747.14 and 748.14) were present, the latter with an isotope pattern indicative of a di-Zn(II) complex (see ESI $\dagger$ ). In order to probe the hydrolysis reaction of $\left[\mathrm{Zn}_{2}(\mathrm{HL1})\left(\mu-\mathrm{CH}_{3} \mathrm{COO}\right)\right]\left(\mathrm{PF}_{6}\right)$, the complex was reacted with the substrate bNPP for $24 \mathrm{~h}$ at $50{ }^{\circ} \mathrm{C}$ in a water-acetonitrile $(90: 10)$ solution and the mass spectrum recorded. The most prominent peak was at $m / z 513.14$, assigned to $[\mathrm{Zn}(\mathrm{HL} 1)+\mathrm{H}]^{+}$; no peaks assigned to phosphate-containing species were observed. The addition of excess $\mathrm{Zn}$ (II) (as $\mathrm{Zn}$ (II) 
acetate) resulted in the appearance of more prominent di- $\mathrm{Zn}$ (II) species $(\mathrm{m} / \mathrm{z} 745.14$ and 747.14$)$.

\section{Potentiometric studies}

The $\mathrm{p} K_{\mathrm{a}}$ values of $\mathrm{H}_{3} \mathrm{~L} 1$ were determined from the potentiometric titration curve obtained when the ligand was titrated in an acetonitrile-water solution $(1: 4, \mathrm{v} / \mathrm{v})$ at $25^{\circ} \mathrm{C}, I=0.1\left(\mathrm{Et}_{4} \mathrm{NClO}_{4}\right)$ with $\mathrm{Et}_{4} \mathrm{NOH}$. The $\mathrm{p} K_{\mathrm{a}}$ values at low $(<3)$ and high $(>9) \mathrm{pH}$ were determined iteratively after fitting the mid-pH range and then holding the obtained fitted parameters fixed in order to fit the extremes of the curve. Once a satisfactory fit was obtained, all the $\mathrm{p} K_{\mathrm{a}}$ values were allowed to refine freely in order to minimise the complete set. The $\mathrm{p} K_{\mathrm{a}}$ values determined were 2.95, assigned to the carboxylic acid, 4.97 and 7.53, assigned to the two pyridine nitrogen atoms, ${ }^{45}$ and 10.97 , which corresponds to the deprotonation of the alcoholic oxygen.

Potentiometric titrations of $\mathrm{Zn}(\mathrm{II})$ and $\mathrm{H}_{3} \mathrm{~L} 1$ with base in the $\mathrm{pH}$ range $2.0-8.5$ in an acetonitrile-water solution $(1: 4, \mathrm{v} / \mathrm{v})$ yielded $\log K_{1}=5.98$ and $\log K_{2}=3.35$ as the simplest model. The fit to the two binding constants was reproducible over a number of different titrations and, when more complicated models including hydroxo ligands were added these were routinely rejected as valid models unless the most rigorous fitting conditions were applied. The simplest model was therefore accepted. The relative magnitudes of the binding constants suggest that one $\mathrm{Zn}$ (II) is bound relatively tightly to $\mathrm{HLI}^{2-}$, and the second more loosely.

\section{Phosphodiesterase-like activity}

The phosphatase-like activity of the proposed $\left[\mathrm{Zn}_{2}(\mathrm{HL} 1)\right.$ $\left.\left(\mathrm{CH}_{3} \mathrm{COO}\right)\right]\left(\mathrm{PF}_{6}\right) \cdot \mathrm{H}_{2} \mathrm{O}$ was measured under conditions of excess substrate, using bNPP (bis-nitrophenyl phosphate). The species tested was the initially prepared $\mathrm{Zn}_{2}$ complex and not the supramolecular $Z_{8}$ complex, which resulted during growth of diffraction-quality crystals. Under the conditions of the mass spectrometer for the complex formulated as $\left[\mathrm{Zn}_{2}(\mathrm{HL} 1)\left(\mathrm{CH}_{3} \mathrm{COO}\right)\right]\left(\mathrm{PF}_{6}\right) \cdot \mathrm{H}_{2} \mathrm{O}$, the acetate is retained in the absence of substrate, however exposure to bNPP results in a species in which the acetate is lost, albeit on prolonged standing. A number of assumptions can be made concerning the catalytically active species. It could be assumed that, to produce a catalytically active species, the acetate ligand partially or completely dissociates, resulting in a complex with either terminal or bridging aqua ligands, $\left[\mathrm{Zn}_{2}(\mathrm{HL} 1)\left(\mathrm{OH}_{2} / \mathrm{OH}\right)_{x}\right]^{m+} \cdot{ }^{28-31,33-35}$ Alternatively, the active species may be an aqua complex $\left[\mathrm{Zn}_{2}(\mathrm{HL} 1)\left(\mu-\mathrm{CH}_{3} \mathrm{COO}\right)\left(\mathrm{OH}_{2}\right)_{x}\right]^{+}$ in which the $\mu$-acetato ligand is retained.

The hydrolysis of bNPP was examined in the presence of added zinc ions and as a function of the concentration of $\left[\mathrm{Zn}_{2}(\mathrm{HL} 1)(\mu-\right.$ $\left.\left.\mathrm{CH}_{3} \mathrm{COO}\right)\right]^{+}$. In all experiments, the effect of added $\mathrm{Zn}$ (II) was negligible up until the addition of two equivalents when a slight rate enhancement was observed. This observation suggests that the most significant active species in solution is a di- $\mathrm{Zn}$ (II) complex based on $\left[\mathrm{Zn}_{2}(\mathrm{HL} 1)\left(\mu-\mathrm{CH}_{3} \mathrm{COO}\right)_{n}\left(\mathrm{OH}_{2} / \mathrm{OH}\right)_{x}\right]^{m+}(n=0$ or 1$)$. It is possible that the presence of substrate stabilises or aids in the assembly of the di- $\mathrm{Zn}$ (II) site, analogous to the suggestion made that in some phosphoesterase systems the reconstitution of a catalytically competent enzyme may only occur in the presence of substrates. ${ }^{2,46}$
The effect of complex concentration, based on $\left[\mathrm{Zn}_{2}(\mathrm{HL} 1)(\mu-\right.$ $\left.\left.\mathrm{CH}_{3} \mathrm{COO}\right)\right]\left(\mathrm{PF}_{6}\right) \cdot \mathrm{H}_{2} \mathrm{O}\left(\mathrm{pH} 9.0 ; 50{ }^{\circ} \mathrm{C}\right)$, on the rate of hydrolysis of bNPP $(1 \mathrm{mM})$ was linear for concentrations of complex from $0.05-0.25 \mathrm{mM}$ (Fig. 5), with a second order rate constant of 7.55 \pm $0.26 \times 10^{-3} \mathrm{M}^{-1} \mathrm{~s}^{-1}$. The addition of extra $\mathrm{Zn}$ (II) had no effect on the rates of the reactions. The $\mathrm{pH}$ dependence on the rate of bNPP cleavage by the complex displays a sigmoidal behaviour in the $\mathrm{pH}$ range 7-9.5. The data were fitted using an equation derived for a monoprotic system, ${ }^{47}$ yielding a $\mathrm{p} K_{\mathrm{a}}$ value of 7.87 (Fig. 6) for the catalytically relevant agent in the model substrate complex.

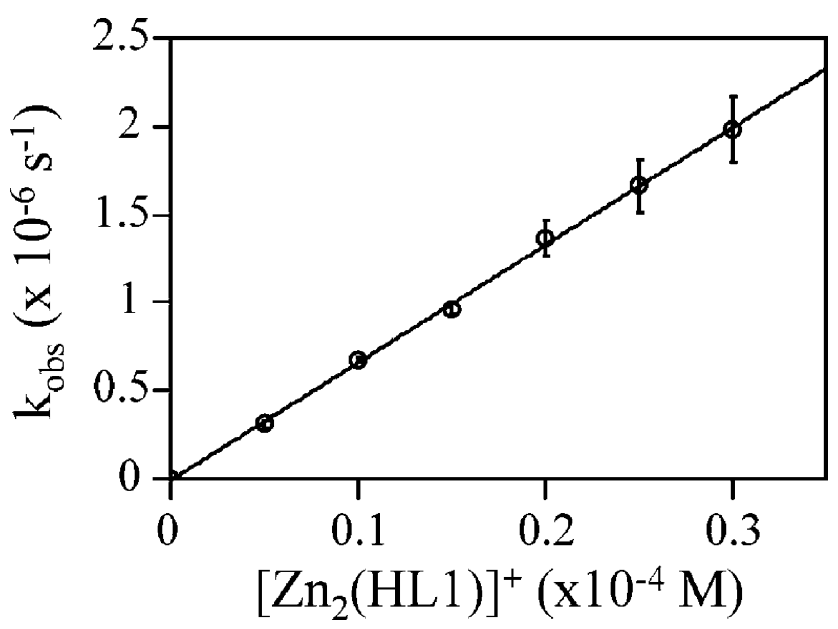

Fig. 5 Dependence of the pseudo-first order rate constant on the concentration of $\left[\mathrm{Zn}_{2}(\mathrm{HL} 1)\right]^{+}$in $88 \mathrm{mM} \mathrm{CHES}$ buffer at $\mathrm{pH} 9.0,50{ }^{\circ} \mathrm{C}$, containing $88 \mathrm{mM} \mathrm{LiClO}_{4}$.

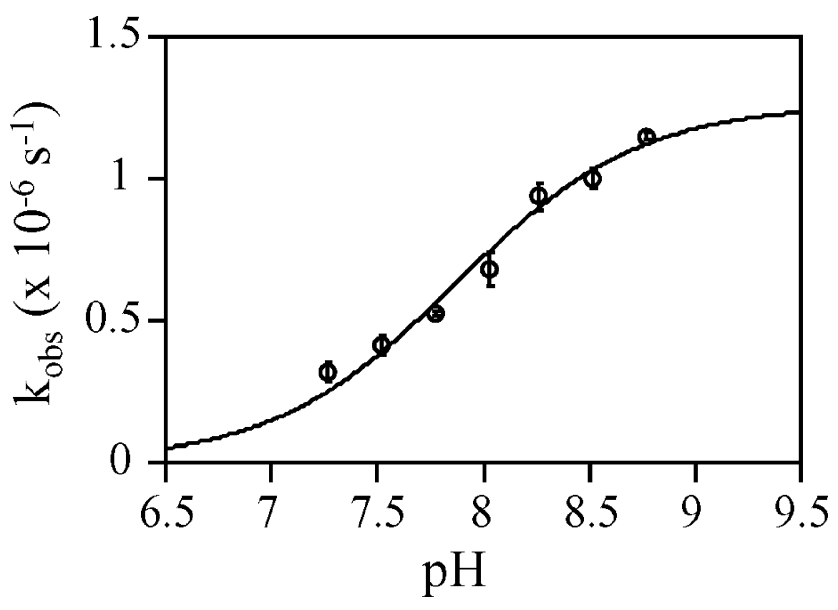

Fig. $6 \mathrm{pH}$ dependence on the reaction rate for $\left[\mathrm{Zn}_{2}(\mathrm{HL} 1)\right]^{+}$.

The initial rate of bNPP cleavage has also been determined as a function of substrate concentration, revealing typical saturation behaviour (Fig. 7). The data were fitted by non-linear regression, using the Michaelis-Menten equation,

$$
\text { Rate }=\frac{V_{\max }[S]}{[S]+K_{\mathrm{M}}},
$$

where $V_{\max }=k_{\text {cat }}\left[\mathrm{Zn}_{2}(\right.$ complex $\left.)\right]$

The substrate concentration at half-maximal rate $\left(K_{\mathrm{M}}\right)$ is $1.96 \pm$ $0.25 \times 10^{-3} \mathrm{M}$ with $V_{\max }=4.37 \pm 0.51 \times 10^{-11} \mathrm{~mol} \mathrm{~L} \mathrm{~s}^{-1}$ and 


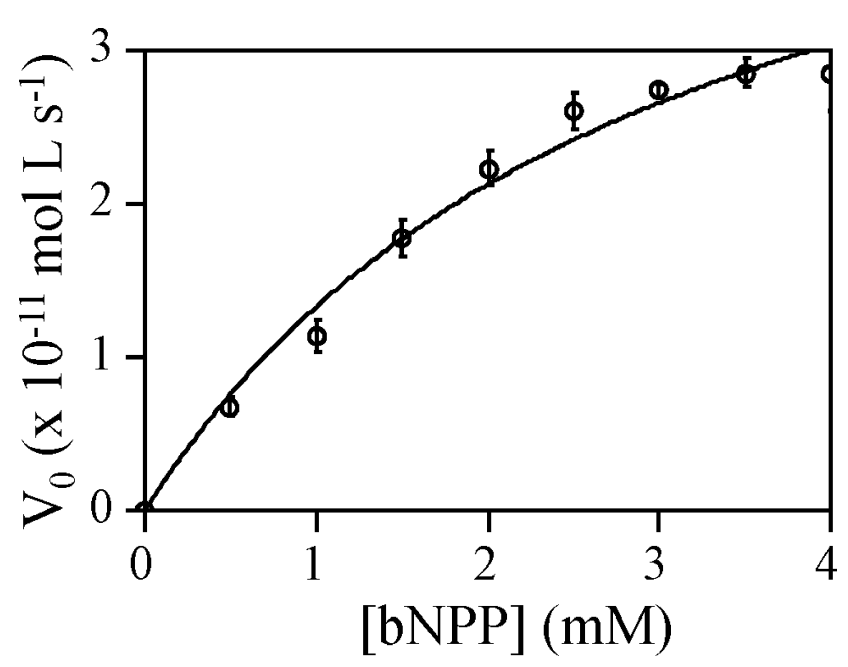

Fig. 7 Dependence on the rate of bNPP cleavage by $\left[\mathrm{Zn}_{2}(\mathrm{HL} 1)\right]^{+}$ $(0.02 \mathrm{mM})$ at $\mathrm{pH} 9.0,50{ }^{\circ} \mathrm{C}, 88 \mathrm{mM} \mathrm{LiClO}_{4}$, [CHES buffer] $88 \mathrm{mM}$.

the corresponding $k_{\text {cat }}=1.26 \pm 0.06 \times 10^{-6} \mathrm{~s}^{-1}$. The indicative substrate binding constant $\left(K_{\mathrm{b}}=1 / K_{\mathrm{M}}\right)$ is $510 \mathrm{M}^{-1}$, suggesting that bNPP is a stronger ligand for $\left[\mathrm{Zn}_{2}(\mathrm{HL} 1)\right]^{2+}$ than it is for the $\mathrm{H}_{2} \mathrm{~L}^{2}$ complex $\left(K_{\mathrm{b}}=16.3 \mathrm{M}^{-1}\right){ }^{28}$ For the analogue $\left[\mathrm{Zn}_{2}(\mathrm{HL} 2)(\mu-\right.$ $\left.\left.\mathrm{CH}_{3} \mathrm{COO}\right)\left(\mathrm{H}_{2} \mathrm{O}\right)\right]\left(\mathrm{PF}_{6}\right)^{28} \quad$ (2,6-bis([(2-pyridylmethyl)(2-hydroxyethyl)amino]methyl)-4-methylphenol $\left.\left(\mathrm{H}_{2} \mathrm{~L}^{-}\right)\right)$under similar reaction conditions $K_{\mathrm{M}}=6.15 \times 10^{-2} \mathrm{M}$ and $k_{\text {cat }}=4.60 \times 10^{-6} \mathrm{~s}^{-1}$ have been reported. ${ }^{28}$

\section{Mechanistic implications}

$\left[\mathrm{Zn}_{2}(\mathrm{HL} 1)\left(\mathrm{CH}_{3} \mathrm{COO}\right)\right]\left(\mathrm{PF}_{6}\right)$ and $\left[\mathrm{Zn}_{2}(\mathrm{HL} 2)\left(\mu-\mathrm{CH}_{3} \mathrm{COO}\right)\left(\mathrm{H}_{2} \mathrm{O}\right)\right]-$ $\left(\mathrm{PF}_{6}\right) \cdot \mathrm{H}_{2} \mathrm{O}$ display catalytically relevant $\mathrm{p} K_{\mathrm{a}}$ values of 7.87 and 7.13, respectively. ${ }^{28}$ Theoretical studies have indicated that the $\mathrm{Zn}$ (II)-alcohol has a lower $\mathrm{p} K_{\mathrm{a}}$ than the $\mathrm{Zn}$ (II)-water in the same molecule. ${ }^{48}$ This, combined with studies in non-aqueous solvents, led to the suggestion that for $\left[\mathrm{Zn}_{2}(\mathrm{HL} 2)\left(\mu-\mathrm{CH}_{3} \mathrm{COO}\right)\left(\mathrm{H}_{2} \mathrm{O}\right)\right]\left(\mathrm{PF}_{6}\right)$, the alcohol hydroxyl, with a $\mathrm{p} K_{\mathrm{a}}$ of 7.20 , is the nucleophile. ${ }^{28}$ The identity of the nucleophile is less clear for $\left[\mathrm{Zn}_{2}(\mathrm{HL} 1)(\mu-\right.$ $\left.\left.\mathrm{CH}_{3} \mathrm{COO}\right)\right]\left(\mathrm{PF}_{6}\right) \cdot \mathrm{H}_{2} \mathrm{O}$. From the $\mathrm{pH}$ dependence studies, the active species was determined to display a $\mathrm{p} K_{\mathrm{a}}$ of 7.87 , typical of that for the deprotonation of a terminal aqua ligand, ${ }^{49}$ although the $\mathrm{p} K_{\mathrm{a}}$ for the deprotonation of a bridging hydroxide is also within this range. ${ }^{50-52}$ The assignment of the catalytic $\mathrm{p} K_{\mathrm{a}}$ is further complicated by the observation that the magnitude of the $\mathrm{Zn}$ (II)aqua $\mathrm{p} K_{\mathrm{a}}$ depends on, amongst other factors, the stereochemistry around the $\mathrm{Zn}$ (II) ion, the metal-metal ion separation, and the extent of hydrogen bonding. Thus, $\mathrm{p} K_{\mathrm{a}}$ values as low as $\sim 4.44$ and as high as 9 are observed with apparently little discrimination between the $\mathrm{p} K_{\mathrm{a}}$ exhibited by the monomeric and dimeric $\mathrm{Zn}$ (II) complexes. ${ }^{28,48,49,52-62}$

The assignment of the catalytically relevant $\mathrm{p} K_{\mathrm{a}}$ of the $\mathrm{Zn}$ (II) complex of $\mathrm{HL}^{2-}$ to either a terminal or metal ion bridging hydroxide is in agreement with the corresponding assignments in $\mathrm{OPH}, \mathrm{OpdA}, \mathrm{GpdQ}$ and various other binuclear metallohydrolases. ${ }^{2,17,19,31,63}$ A combination of the experimental and theoretical (computational) studies of OPH suggests that the bridging hydroxide with a $\mathrm{p} K_{\mathrm{a}}$ of 8.4 is the nucleophile in phosphate ester hydrolysis. ${ }^{20,63,64}$ Other binuclear metallohydrolases that are reported to initiate hydrolysis with the $\mu$-hydroxide include, amongst others, some purple acid phosphatases, arginases and ureases. ${ }^{31,65-69}$ In contrast, a recent crystallographic study showing trapped substrates bound to the active site of OpdA suggests that in this enzyme the nucleophile is monodentately bound to the $\alpha$-metal site (Fig. 1). ${ }^{20}$ Clearly, there is substantial ambiguity and variety with respect to assigning nucleophiles. In an attempt to reconcile these different strategies, it has been suggested that the $\mu$-hydroxo is the actual source of the nucleophile, but that substrate binding triggers the displacement of the $\mu-\mathrm{OH}$ to form a quasiterminal hydroxide, coordinated predominantly to the more buried or $\alpha$ - site. $^{70,71}$

While it is no trivial task to deconvolute the precise details of the catalytic mechanism(s) employed by binuclear hydrolytic systems, it has emerged that subtle variations in the first and second coordination environment and differences in the metal ion composition have less subtle effects on that mechanism(s). ${ }^{2}$ For instance, for purple acid phosphatase extracted from the pig uterine fluid (uteroferrin) the likely nucleophile for the FeFe and $\mathrm{FeZn}$ metal ion combinations is a terminally bound hydroxide, ${ }^{72}$ while for the GaZn, FeNi and possibly FeMn combinations, the $\mu$-hydroxide is the likely candidate nucleophile. ${ }^{31,35}$ Similarly, different nucleophiles are proposed by different groups for the highly homologous OPH and OpdA ( $~ 90 \%$ sequence identity) ${ }^{9,10,17}$

In summary, despite the ambiguity of the assignment of the catalytically relevant $\mathrm{p} K_{\mathrm{a}}$ values for the $\mathrm{Zn}$ (II) complex of $\mathrm{HL}^{2-}$, the mechanistic features of the model system are in good agreement with those of the corresponding enzymatic systems.

\section{Conclusions}

Effective biomimetics are expected to display both the structural and functional characteristics of the metallobiosite. ${ }^{24-29}$ In the case of both $\mathrm{HL1}^{2-}$ and $\mathrm{H}_{2} \mathrm{~L}_{2}{ }^{-28}$, the zinc complexes mimic aspects of the features of the metallobiosites of OPH, OpdA and $\mathrm{GpdQ}, \mathrm{HL1}^{2-}$, in particular, appearing to present a strong and loose binding site, analogous to the situation observed in the enzymes. Modelling the activity and the exact nucleophilic agent is more problematic. The catalytic activity of the $\mathrm{Zn}$ (II) complexes of $\mathrm{HL}^{2-}$ and HL2- appears typical of that exhibited by similar complexes, although it is difficult to make definitive comparisons due to the different reaction conditions employed. ${ }^{28,52}$ Whilst the $k_{\text {cat }}$ of $\sim 1.5 \times 10^{-6} \mathrm{~s}^{-1}$ represents considerable enhancement over the uncatalyzed rate $\left(1.1 \times 10^{-11} \mathrm{~s}^{-1}\right)^{73}$ the enhancement does not approach the catalytic rate of the metalloenzymes (the catalytic rates for OPH and OpdA are $\left.>1000 \mathrm{~s}^{-1}\right)$. ${ }^{13,15,16}$ There are strategies, however, that reportedly lead to an enhanced activity for biomimetic systems. ${ }^{59,74}$ Considering the potential applications of OPH, OpdA and GpdQ for bioremediation, it is an attractive endeavour to develop more robust biomimetic systems exhibiting sufficient structural and functional stability to be used practically.

\section{Experimental}

\section{Instrumental methods}

NMR spectra were measured using Bruker AV400 (400 MHz) and AV500 (500 MHz) instruments. The spectra were recorded in $\mathrm{CDCl}_{3}$, with chemical shifts reported in parts per million (ppm) and calibrated using the resonances for $\mathrm{CDCl}_{3}$, 
$\delta_{\mathrm{H}}\left(\mathrm{CHCl}_{3}\right)=7.24 \mathrm{ppm}$ and $\delta_{\mathrm{C}}\left(\mathrm{CDCl}_{3}\right)=77.0 \mathrm{ppm}$. Low and high-resolution positive-ion mass spectra were obtained using either a Q-Star time-of-flight mass spectrometer, in methanol or acetonitrile, using $10 \%$ acetic or formic acid carrier liquid or a Finnigan MAT 900 XL mass spectrometer and methanol solutions for the ligand, and acetonitrile for the metal complex. All samples were subjected to electrospray ionisation, with voltages tuned to optimise the signals. The predicted isotopic splitting patterns of peaks were calculated using the program Molecular Weight Calculator. ${ }^{75}$ Infrared spectroscopy was performed with a Perkin Elmer FT-IR SPECTRUM 2000 spectrometer with a Smiths DuraSamplIR II ATR diamond window. Elemental analyses were performed using the microanalysis facilities at The University of Queensland.

\section{Syntheses of the ligands and metal complex}

2,6-Bis(chloromethyl)-4-methyl-phenol, $N$-(2-pyridylmethyl) glycine ethyl ester, $N$-(2-pyridylmethyl)-2-aminoethanol were prepared as described previously. ${ }^{36-38}$

[Ethyl-2-((2-hydroxy-3-(((2-hydroxyethyl)(pyridin-2-ylmethyl)amino)methyl)-5-methylbenzyl)(pyridin-2-ylmethyl)amino)acetate] (H2 $\mathbf{H}_{2}$ EtL1). $\quad \mathrm{H}_{2}$ EtL1 was synthesised from 2,6-bis(chloromethyl)4-methyl-phenol, $N$-(2-pyridylmethyl)glycine ethyl ester and $N$-(2-pyridylmethyl)-2-aminoethanol using a statistical reaction. Thus, $N$-(2-pyridylmethyl) glycine ethyl ester (1.12 g, $5.76 \mathrm{mmol})$ and $N$-(2-pyridylmethyl)-2-aminoethanol (0.88 g, $5.8 \mathrm{mmol})$ were dissolved in $9 \mathrm{~mL}$ of tetrahydrofuran (THF) with $1.15 \mathrm{~g}$ triethylamine (TEA) $(11.48 \mathrm{mmol})$. Separately, 2,6-bis(chloromethyl)-4-methyl-phenol (1.18 g, $5.76 \mathrm{mmol})$ was dissolved in $8 \mathrm{~mL}$ dichloromethane (DCM) and added dropwise under stirring into the TEA solution at $0{ }^{\circ} \mathrm{C}$. The mixture was stirred at room temperature for $48 \mathrm{~h}$, the precipitated TEA. $\mathrm{HCl}$ was filtered off, and the solvent was removed by rotary evaporation. The residue was taken up in DCM $(50 \mathrm{~mL})$, washed with concentrated aqueous $\mathrm{NaCl}(20 \mathrm{~mL})$, the organic layer dried over anhydrous sodium sulfate, filtered and the solvent removed in vacuo, to yield an orange oil (2.35 g). NMR and TLC of the mixture revealed a combination of three products. The separation of the products was achieved with column chromatography (silica; $80: 20$, ethyl acetate-methanol). The first product eluted from the column $\left(R_{\mathrm{f}}: 0.89\right)$ was determined to be [diethyl-2,20-(2hydroxy - 5 - methyl - 1,3 - phenylene)bis(methylene)bis((pyridin - 2 ylmethyl)azanediyl)diacetate] $(0.4 \mathrm{~g})$. NMR $\delta_{\mathrm{H}} / \mathrm{ppm}(500 \mathrm{MHz}$, $\left.\mathrm{CDCl}_{3}\right): 1.21\left(6 \mathrm{H}, \mathrm{t}, J=7.15 \mathrm{~Hz}, \mathrm{CH}_{2} \mathrm{CH}_{3}\right), 2.18\left(3 \mathrm{H}, \mathrm{s}, \mathrm{Ar}-\mathrm{CH}_{3}\right)$, $3.37\left(4 \mathrm{H}, \mathrm{s}, \mathrm{CH}_{2}\right), 3.84\left(4 \mathrm{H}, \mathrm{s}, \mathrm{CH}_{2}\right), 3.93\left(4 \mathrm{H}, \mathrm{s}, \mathrm{CH}_{2}\right), 4.12(2 \mathrm{H}$, q, $\left.J=7.22 \mathrm{~Hz}, \mathrm{CH}_{2} \mathrm{CH}_{3}\right), 6.91(2 \mathrm{H}, \mathrm{s}, \mathrm{Ar}-\mathrm{H}), 7.09(2 \mathrm{H}, \mathrm{qd}, J=$ $1.65 \mathrm{~Hz}, 1.17$, py-CH), $7.45(2 \mathrm{H}, \mathrm{dt}, J=7.89 \mathrm{~Hz}, 1.01$, py-CH) $7.59(2 \mathrm{H}, \mathrm{td}, J=3.85 \mathrm{~Hz}, 1.80$, py-CH) $8.47(2 \mathrm{H}, \mathrm{dq}, J=$ $4.93 \mathrm{~Hz}, 0.91$, py-CH). NMR $\delta_{\mathrm{C}} / \mathrm{ppm}\left(500 \mathrm{MHz}, \mathrm{CDCl}_{3}\right): 14.12$ $\left(\mathrm{CH}_{2} \mathrm{CH}_{3}\right), 20.39\left(\mathrm{Ar}-\mathrm{CH}_{3}\right), 54.32,59.41,60.43\left(\mathrm{CH}_{2}\right), 122.02$ (Ar-C), 123.10, 123.14 (py-CH), 127.56 (Ar-CH), 130.05 (Ar-C), 136.56, 148.77 (py-CH), 153.48 (Ar-C), 158.74 (py-C), 171.31 $(\mathrm{C}=\mathrm{O}) . \quad m / z: 521.22\left(\mathrm{C}_{29} \mathrm{H}_{37} \mathrm{~N}_{4} \mathrm{O}_{5}, \mathrm{M}^{+}\right), 479.22\left(\mathrm{C}_{27} \mathrm{H}_{35} \mathrm{~N}_{4} \mathrm{O}_{4}\right)$, $327.17\left(\mathrm{C}_{19} \mathrm{H}_{23} \mathrm{~N}_{2} \mathrm{O}_{3}\right), 286.16\left(\mathrm{C}_{17} \mathrm{H}_{22} \mathrm{~N}_{2} \mathrm{O}_{2}\right), 195.13\left(\mathrm{C}_{10} \mathrm{H}_{15} \mathrm{~N}_{2} \mathrm{O}_{2}\right)$. The second product to be eluted $\left(R_{\mathrm{f}}: 0.59\right)$ was identified as the target product $(0.65 \mathrm{~g})$. NMR $\delta_{\mathrm{H}} / \mathrm{ppm}\left(500 \mathrm{MHz}, \mathrm{CDCl}_{3}\right)$ : $1.19\left(3 \mathrm{H}, \mathrm{t}, J=7.15 \mathrm{~Hz}, \mathrm{CH}_{2} \mathrm{CH}_{3}\right), 2.15\left(3 \mathrm{H}, \mathrm{s}, \mathrm{Ar}-\mathrm{CH}_{3}\right), 2.70$ $\left(2 \mathrm{H}, \mathrm{t}, J=5.18 \mathrm{~Hz}, \mathrm{NCH}_{2} \mathrm{CH}_{2}\right), 3.33\left(2 \mathrm{H}, \mathrm{s}, \mathrm{CH}_{2}\right), 3.66(2 \mathrm{H}$, t, $\left.J=5.28 \mathrm{~Hz}, \mathrm{CH}_{2} \mathrm{OH}\right), 3.72\left(2 \mathrm{H}, \mathrm{s}, \mathrm{CH}_{2}\right), 3.79\left(2 \mathrm{H}, \mathrm{s}, \mathrm{CH}_{2}\right)$, $3.80\left(2 \mathrm{H}, \mathrm{s}, \mathrm{CH}_{2}\right), 3.92\left(2 \mathrm{H}, \mathrm{s}, \mathrm{CH}_{2}\right), 4.12(2 \mathrm{H}, \mathrm{q}, J=7.14 \mathrm{~Hz}$, $\left.\mathrm{CH}_{2} \mathrm{CH}_{3}\right), 6.78(1 \mathrm{H}, \mathrm{d}, J=1.90 \mathrm{~Hz}, \mathrm{Ar}-\mathrm{H}), 6.85(1 \mathrm{H}, \mathrm{d}, J=$ $1.85 \mathrm{~Hz}, \mathrm{Ar}-\mathrm{H}), 7.03(1 \mathrm{H}, \mathrm{qd}, J=1.67 \mathrm{~Hz}, 1.05$, py-CH), 7.11 $(1 \mathrm{H}, \mathrm{qd}, J=1.63 \mathrm{~Hz}, 1.03$, py-CH), $7.34(1 \mathrm{H}, \mathrm{dt}, J=7.88 \mathrm{~Hz}$, 1.01 , py-CH), $7.44(1 \mathrm{H}, \mathrm{td}, J=3.88 \mathrm{~Hz}, 1.85$, py-CH), $7.59(1 \mathrm{H}$, $\mathrm{td}, J=3.84 \mathrm{~Hz}, 1.82$, py-CH), $8.40(1 \mathrm{H}, \mathrm{dq}, J=4.93 \mathrm{~Hz}, 0.86$, py-CH), $8.50\left(1 \mathrm{H}, \mathrm{dq}, J=4.75 \mathrm{~Hz}, 0.83\right.$, py-CH). NMR $\delta_{\mathrm{C}} / \mathrm{ppm}$ $\left(500 \mathrm{MHz}, \mathrm{CDCl}_{3}\right): 14.08\left(\mathrm{CH}_{2} \mathrm{CH}_{3}\right), 20.29\left(\mathrm{Ar}-\mathrm{CH}_{3}\right), 53.96$, 54.50, 55.05, 55.70, 58.87, 59.09, 59.41, $60.52\left(\mathrm{CH}_{2}\right), 121.84$, 121.99 (py-CH), 122.19, 122.36 (Ar-C), 122.99, 123.08 (py-CH), 127.45 (Ar-C), 129.88, $130.70(\mathrm{Ar}-\mathrm{CH}), 136.38,136.70,148.46$, 148.80 (py-CH), 153.51 ( $\mathrm{Ar}-\mathrm{C}), 157.96$ (py-C), $171.03(\mathrm{C}=\mathrm{O})$. $m / z$ : $479.22\left(\mathrm{C}_{27} \mathrm{H}_{35} \mathrm{~N}_{4} \mathrm{O}_{4}, \mathrm{M}^{+}\right), 388.22\left(\mathrm{C}_{21} \mathrm{H}_{30} \mathrm{~N}_{3} \mathrm{O}_{4}\right), 327.17$ $\left(\mathrm{C}_{19} \mathrm{H}_{23} \mathrm{~N}_{2} \mathrm{O}_{3}\right), 285.17\left(\mathrm{C}_{17} \mathrm{H}_{21} \mathrm{~N}_{2} \mathrm{O}_{2}\right), 242.29\left(\mathrm{C}_{15} \mathrm{H}_{18} \mathrm{~N}_{2} \mathrm{O}\right)$. The third product eluted $\left(R_{\mathrm{f}}: 0.30\right)$ was symmetric $\mathrm{H}_{3} \mathrm{~L} 2(0.33 \mathrm{~g})$. NMR $\delta_{\mathrm{H}} / \mathrm{ppm}\left(500 \mathrm{MHz}, \mathrm{CDCl}_{3}\right): 2.17\left(3 \mathrm{H}, \mathrm{s}, \mathrm{Ar}-\mathrm{CH}_{3}\right) ; 2.69$ $\left(4 \mathrm{H}, \mathrm{t}, J=5.20 \mathrm{~Hz}, 2 \times \mathrm{NCH}_{2} \mathrm{CH}_{2} \mathrm{OH}\right) ; 3.64(4 \mathrm{H}, \mathrm{t}, J=5.23 \mathrm{~Hz}$, $\left.2 \times \mathrm{NCH}_{2} \mathrm{CH}_{2} \mathrm{OH}\right) ; 3.72\left(4 \mathrm{H}, \mathrm{s}, 2 \times \mathrm{CH}_{2}\right) ; 3.84\left(4 \mathrm{H}, \mathrm{s}, 2 \times \mathrm{CH}_{2}\right)$; $6.79(2 \mathrm{H}, \mathrm{s}, 2 \times \mathrm{Ar}-\mathrm{H}) ; 7.10(2 \mathrm{H}, \mathrm{qd}, J=1.70 \mathrm{~Hz}, 1.10$, py-CH), $7.26(2 \mathrm{H}, \mathrm{dt}, J=7.88 \mathrm{~Hz}, 1.19$, py-CH), $7.54(2 \mathrm{H}, \mathrm{td}, J=3.85 \mathrm{~Hz}$, 1.85 , py-CH), 8.49 (2H, dq, $J=5.13 \mathrm{~Hz}, 0.85$, py-CH). NMR $\delta_{\mathrm{C}} / \mathrm{ppm}\left(500 \mathrm{MHz}, \mathrm{CDCl}_{3}\right): 20.38\left(\mathrm{Ar}-\mathrm{CH}_{3}\right), 55.75,55.99,59.31$ $59.34\left(\mathrm{CH}_{2}\right), 122.14,123.16$ (py-CH), 123.70, 127.56, 130.32 (Ar-CH), 136.68, 148.81 (py-CH), 153.71 (Ar-CH), 158.79 (py-CH). $m / z$ : $437.21\left(\mathrm{C}_{25} \mathrm{H}_{33} \mathrm{~N}_{4} \mathrm{O}_{3}, \mathrm{M}^{+}\right), 285.17\left(\mathrm{C}_{17} \mathrm{H}_{21} \mathrm{~N}_{2} \mathrm{O}_{2}\right)$, $242.29\left(\mathrm{C}_{15} \mathrm{H}_{18} \mathrm{~N}_{2} \mathrm{O}\right), 153.11\left(\mathrm{C}_{8} \mathrm{H}_{13} \mathrm{~N}_{2} \mathrm{O}\right)$.

Lithium salt of [2-((2-hydroxy-3-(((2-hydroxyethyl)(pyridin-2-ylmethyl)amino)methyl)-5-methylbenzyl)(pyridin-2-ylmethyl)amino)acetic acid] $\left(\mathbf{L i H}_{2} \mathbf{L 1}\right)$. A methanol solution of $\mathrm{LiOH}(0.1 \mathrm{M})$ was prepared from $0.2115 \mathrm{~g} \mathrm{LiOH}$ in $100 \mathrm{~mL}$ methanol. $\mathrm{H}_{2}$ EtL1 $(0.1087 \mathrm{~g}, 0.227 \mathrm{mmol})$ was dissolved in $\mathrm{MeOH}(1 \mathrm{~mL}), 2.27 \mathrm{~mL}$ of the LiOH-methanol solution was added and the mixture stirred for $48 \mathrm{~h}$. Removal of the solvent in vacuo giving $\mathrm{LiH}_{2} \mathrm{~L} 1$ as a yellow oil $(0.10 \mathrm{~g})$. NMR $\delta_{\mathrm{H}} / \mathrm{ppm}\left(400 \mathrm{MHz}, \mathrm{CDCl}_{3}\right): 2.54$ (2, $\left.\mathrm{NCH}_{2} \mathrm{CH}_{2}\right), 3.30-3.85\left(12, \mathrm{CH}_{2}\right), 4.12,6.61-6.71(2, \mathrm{Ar}-\mathrm{H})$, 6.99-8.33 (8, py-CH). NMR $\delta_{\mathrm{C}} / \mathrm{ppm}\left(400 \mathrm{MHz}, \mathrm{CDCl}_{3}\right): 19.69$ and $19.87\left(\mathrm{Ar}-\mathrm{CH}_{3}\right), 51.00-59.27\left(\mathrm{CH}_{2}\right), 60.61\left(\mathrm{CH}_{2}\right), 121.64$ (py-CH), 121.88 (py-CH), 122.02 (Ar-tert-C), 122.69 (py-CH), 122.80 (py-CH), 136.39 (Ar-CH), 136.43 (py-CH), 136.69 (py-CH), 148.33 (py-CH), 157.51 (Ar-C), 158.30 (py-C), 159.61 (py-C), $171.20(\mathrm{C}=\mathrm{O})$.

$\left[\mathrm{Zn}_{2}(\mathrm{HL1})\left(\mathrm{CH}_{3} \mathrm{COO}\right)\right]\left(\mathrm{PF}_{6}\right) \cdot \mathrm{H}_{2} \mathrm{O}$ and $\mathrm{Li}\left[\mathrm{Zn}_{2}(\mathrm{HL1})\right]_{4}\left(\mathrm{PO}_{4}\right)_{2}-$ $\left(\mathbf{P F}_{6}\right)_{3} \cdot\left(\mathbf{C H}_{3} \mathbf{O H}\right) . \quad \mathrm{LiH}_{2} \mathrm{~L} 1(0.10 \mathrm{~g}, 0.219 \mathrm{mmol})$ was dissolved in methanol $(1 \mathrm{~mL})$. To this was added zinc acetate $(0.0481 \mathrm{~g}$, $0.219 \mathrm{mmol}$ ) dissolved in methanol dropwise with stirring. The resulting mixture was refluxed gently for $30 \mathrm{~min}$ then permitted to cool to room temperature. $\mathrm{NaPF}_{6}(0.0550 \mathrm{~g}$, $0.327 \mathrm{mmol})$ was dissolved in methanol $(4 \mathrm{~mL})$ and added and the solution was left to sit at room temperature. Slow evaporation and subsequent filtration produced a creamy white solid (53.6 mg, 77\%). Found: C 40.75, H 4.11, N 7.00\%. Calcd for $\left[\mathrm{Zn}_{2}\left(\mathrm{C}_{25} \mathrm{H}_{28} \mathrm{~N}_{4} \mathrm{O}_{4}\right)\left(\mathrm{CH}_{3} \mathrm{COO}\right)\right]\left(\mathrm{PF}_{6}\right) \cdot \mathrm{H}_{2} \mathrm{O}$ : C 40.47, H 4.15, $\mathrm{N} 7.00 \%$. NMR $\delta_{\mathrm{H}} / \mathrm{ppm}(400 \mathrm{MHz}, \mathrm{DMSO}): 1.98\left(\mathrm{Ar}-\mathrm{CH}_{3}\right)$, $2.06\left(\mathrm{NCH}_{2} \mathrm{CH}_{2} \mathrm{OH}\right), 2.78\left(\mathrm{CH}_{2} \mathrm{OH}\right), 2.16-3.23\left(\mathrm{CH}_{2}\right), 3.51-$ $4.04\left(\mathrm{CH}_{2}\right), 6.54$ and $6.66(\mathrm{ArH}), 6.80-8.55($ py-CH). NMR $\delta_{\mathrm{C}} / \mathrm{ppm}(400 \mathrm{MHz}, \mathrm{DMSO}): 19.70$ and $19.77\left(\mathrm{CH}_{3}\right), 54.65$, 55.33, 55.95, 56.72, 58.25, 58.85, $60.95\left(\mathrm{CH}_{2}\right), 121.76(\mathrm{Ar}-\mathrm{C})$, 
$123.05,123.31,123.81,124.61$ (py-CH), $131.79(\mathrm{Ar}-\mathrm{CH}), 139.02$, 139.74, 146.55, 147.26 (py-CH), 154.96 (Ar-C), 159.65 (py-C), $173.05(\mathrm{C}=\mathrm{O}), 177.75(\mathrm{Ar}-\mathrm{C})$. ES-MS $m / z$ : 623.10 and 625.1 $\left[\mathrm{Zn}_{2} \mathrm{C}_{25} \mathrm{H}_{28} \mathrm{~N}_{4} \mathrm{O}_{4}(\mathrm{CHOO})\right]^{+} ; 577.09$ and $579.1\left[\mathrm{Zn}_{2} \mathrm{C}_{25} \mathrm{H}_{27} \mathrm{~N}_{4} \mathrm{O}_{4}\right]^{+}$; $513.17\left[\mathrm{ZnC}_{25} \mathrm{H}_{29} \mathrm{~N}_{4} \mathrm{O}_{4}\right]^{+}$. FT-IR spectra $\left(v / \mathrm{cm}^{-1}\right): 1605.23(\mathrm{~m}$, $\mathrm{C}=\mathrm{O}$ str), $1568.99(\mathrm{~m}$, phenol and py $\mathrm{C}=\mathrm{C}$ str), $1478.21(\mathrm{~m}$, py $\mathrm{CH}$ str), 1433.29 (m, py CH stretch), 1397.61 (m, $\mathrm{CH}_{2} \mathrm{CO}$ def), 1267.72 (w, tertiary NC str), 1057.55, 1019.42 (w, COH str) 824.80 (vs. $\mathrm{PF}_{6}^{-}$), 797.90, 765.92 (m, m, py CH def), $554.96\left(\mathrm{~s}, \mathrm{PF}_{6}{ }^{-}\right)$.

Crystallisation of the complex proved to be difficult. A screening method was devised using crystallisation wells to screen solution environments for precipitating crystals. Acetate, nitrate, sulfate and phosphate anions were screened with differing quantities of the counter ion $\mathrm{PF}_{6}{ }^{-}$or $\mathrm{ClO}_{4}{ }^{-}$. The only environment to produce crystals was in the presence of hexafluorophosphate. Thus, the bulk reaction mixture was left to stand in the presence of $\mathrm{PF}_{6}{ }^{-}$resulting, after $4 \mathrm{~d}$, a small crystal suitable for X-ray diffraction studies. This complex was subsequently characterised crystallographically as $\mathrm{Li}\left[\mathrm{Zn}_{2}(\mathrm{HL} 1)\right]_{4}\left(\mathrm{PO}_{4}\right)_{2}\left(\mathrm{PF}_{6}\right)_{3} \cdot\left(\mathrm{CH}_{3} \mathrm{OH}\right)$.

\section{Crystallographic measurements}

X-Ray diffraction data for a crystal of $\mathrm{Li}\left[\mathrm{Zn}_{2}(\mathrm{HL} 1)\right]_{4}\left(\mathrm{PO}_{4}\right)_{2}\left(\mathrm{PF}_{6}\right)_{3}$. $\left(\mathrm{CH}_{3} \mathrm{OH}\right)$ were collected with a Bruker APEX II diffractometer with graphite monochromated $\operatorname{MoK} \alpha(\lambda=0.71073 \AA)$ radiation. The structure was solved by direct methods using SIR $97^{76}$ and refined on $F^{2}$ using SHELXL-9777 running within the WinGX interface. ${ }^{78}$ Plots were drawn using the ORTEP program. ${ }^{79}$ The hydrogen positions for the alcohol, methylene and coordinated water molecules were calculated and included in the final refinement cycle. All non-hydrogen atoms were refined with anisotropic thermal parameters. Selected crystal data and details of refinements are given in Table 1.

\section{Catalytic studies}

Catalytic studies on the zinc complexes of $\mathrm{H}_{3} \mathrm{~L} 1$ were performed with bNPP, which hydrolyses to form 4-nitrophenolate and 4nitrophenyl phosphate. The hydrolysis was followed by monitoring the formation of 4-nitrophenol at $50^{\circ} \mathrm{C}$ at $400 \mathrm{~nm}$. The extinction coefficient at $400 \mathrm{~nm}$ for 4-nitrophenol is $\mathrm{pH}$ dependent and was experimentally determined for each relevant $\mathrm{pH}$ to kinetic experiments. All studies were performed in $3 \mathrm{~mL}$ reaction aliquots using the substrate bNPP (30 mM stock), buffers (MES, HEPES, Tris, CHES, $100 \mathrm{mM}$, aq.), and catalytic species $\mathrm{Zn}_{2} \mathrm{H}_{2} \mathrm{~L} 1$ and $\mathrm{Zn}\left(\mathrm{NO}_{3}\right)_{2}$ in acetonitrile (all at $1 \mathrm{mM}$ ). All experiments were run in triplicate. The protocol for initialising the hydrolysis reaction was to add $0.3 \mathrm{~mL}$ of an acetonitrile solution of the zinc complex to the calculated amount of buffer in the test tubes. Where appropriate, excess $\mathrm{Zn}\left(\mathrm{NO}_{3}\right)_{2}$ was added to the test tubes. $0.1 \mathrm{~mL}$ bNPP was added, the solution was mixed and the absorbance at $400 \mathrm{~nm}$ measured. The reaction vessels were placed in a $50{ }^{\circ} \mathrm{C}$ water bath and the absorbance recorded at specified time intervals. The zinc dependence of bNPP hydrolysis by the $\mathrm{Zn}_{2} \mathrm{H}_{2} \mathrm{~L} 1$ was investigated by performing kinetic experiments at varying molar equivalents of $\mathrm{Zn}\left(\mathrm{NO}_{3}\right)_{2}$ added to the reaction mixture. Control experiments were also run in identical environments in the presence of $\mathrm{Zn}\left(\mathrm{NO}_{3}\right)_{2}$ and absence of complex. The final concentrations in $3 \mathrm{~mL}$ were as described above and the final concentrations of added zinc were
$0,0.1,0.2,0.3,0.4,0.6,0.8$ and $1 \mathrm{mM}$, respectively, leading to a $1-$ 10 -fold excess of zinc. The effect of $\mathrm{pH}$ on the hydrolytic reaction was studied in the $\mathrm{pH}$ range $6.5-10$ with the $\mathrm{Zn}_{2} \mathrm{H}_{2} \mathrm{Ll}$, and no excess zinc. The reactions were followed to $5 \%$ of bNPP hydrolysis. The kinetic experiments, as a function of substrate concentration, were performed at $\mathrm{pH} 9$. The concentration of bNPP in the final $3 \mathrm{~mL}$ reactions was $0.5,1.0,1.5$ and $2.0 \mathrm{mM}$, respectively.

\section{Potentiometric titrations}

Titrant solutions of acid $\left(\mathrm{HClO}_{4}\right)$ were standardised against Borax and titrant solutions of $\mathrm{Et}_{4} \mathrm{NOH}$ were standardised against the previously standardised $\mathrm{HClO}_{4}$. Potentiometric titrations were performed with a Metrohm 665 Dosimat. The e.m.f. was measured with an ORION model 720A pH meter with a glass electrode. All titrations were carried out at a constant ionic strength of $0.1 \mathrm{M}$ $\mathrm{Et}_{4} \mathrm{NClO}_{4}$ and were performed under a nitrogen atmosphere at $25{ }^{\circ} \mathrm{C}$. For each titration the $\mathrm{pH}$ meter was calibrated using pH 6.88 and 4.00 buffers and a calibration titration was performed to determine $E_{\mathrm{o}}$ and $\mathrm{p} K_{\mathrm{w}}$ values. Potentiometric titrations were performed on both the free ligands and in the presence of zinc perchlorate under a $\mathrm{MeCN}-\mathrm{H}_{2} \mathrm{O}$ saturated nitrogen atmosphere at $25^{\circ} \mathrm{C}$. The reaction vessel contained $2 \mathrm{~mL}$ of product $(5 \mathrm{mM})$ in acetonitrile, acidified with $8 \mathrm{~mL} \mathrm{HClO}_{4}(6.8 \mathrm{mM})$. The final concentration of the product was therefore $1 \mathrm{mM}$ in an acetonitrile-water $(1: 4, \mathrm{v} / \mathrm{v})$ solution. The ionic strength was kept constant at $0.1 \mathrm{M}$ with $\mathrm{Et}_{4} \mathrm{NClO}_{4}$. Calibration titrations were conducted using constant volume increments $(0.02 \mathrm{~mL})$ of $0.109 \mathrm{M}$ $\mathrm{Et}_{4} \mathrm{NOH}$ solution. Reactant titrations were performed by keeping the $\mathrm{mV}$ change constant $(-4 \mathrm{mV})$. The curve fitting of all the data was performed using SUPERQUAD ${ }^{80}$ and all $\mathrm{p} K_{\mathrm{a}}$ values were reproducible within 0.5 units.

\section{Acknowledgements}

This work was funded by a grant from the Australian Research Council (DP0664039).

\section{References}

1 F. Ely, J. L. Foo, C. J. Jackson, L. R. Gahan, D. L. Ollis and G. Schenk, Curr. Top. Biochem. Res., 2007, 9, 63-78.

2 N. Mitic, S. J. Smith, A. Neves, L. W. Guddat, L. R. Gahan and G. Schenk, Chem. Rev., 2006, 106, 3338-3363.

3 E. Kimura, Curr. Opin. Chem. Biol., 2000, 4, 207-213.

4 E. Ghanem, Y. Li, C. Xu and F. M. Raushel, Biochemistry, 2007, 46, 9032-9040.

5 M. M. Benning, J. M. Kuo, F. M. Raushel and H. M. Holden, Biochemistry, 1994, 33, 15001-15007.

6 E. Ghanem and F. M. Raushel, Toxicol. Appl. Pharmacol., 2005, 207, S459-470.

7 D. P. Dumas, S. R. Caldwell, J. R. Wild and F. M. Raushel, J. Biol. Chem., 1989, 264, 19659-19665.

8 S. S. Rowland, M. K. Speedie and B. M. Pogell, Appl. Environ. Microbiol., 1991, 57, 440-444.

9 H. Yang, P. D. Carr, S. Y. McLoughlin, J.-W. Liu, I. Horne, X. Qiu, C. M. J. Jeffries, R. J. Russell, J. G. Oakeshott and D. L. Ollis, Protein Eng., 2003, 16, 135-145.

10 I. Horne, T. D. Sutherland, R. L. Harcourt, R. J. Russell and J. G. Oakeshott, Appl. Environ. Microbiol., 2002, 68, 3371-3376.

11 J. A. Gerlt and W. H. Y. Wan, Biochemistry, 1979, 18, 4630-4638.

12 S. Y. McLoughlin, C. J. Jackson, J.-W. Liu and D. L. Ollis, Appl. Environ. Microbiol., 2004, 70, 404-412.

13 C. J. Jackson, P. D. Carr, J.-W. Liu and S. J. Watt, J. Mol. Biol., 2007, 367, 1047-1062. 
14 C. J. Jackson, P. D. Carr, H.-K. Kim, J.-W. Liu, P. Herrald, N. Mitic, G. Schenk, C. A. Smith and D. L. Ollis, Biochem. J., 2006.

15 G. A. Omburo, J. M. Kuo, L. S. Mullins and F. M. Raushel, J. Biol. Chem., 1992, 267, 13278-13283.

16 M. M. Benning, H. Shim, F. M. Raushel and H. M. Holden, Biochemistry, 2001, 40, 2712-2722.

17 S. D. Aubert, Y. Li and F. M. Raushel, Biochemistry, 2004, 43, 57075715.

18 M. M. Benning, J. M. Kuo, F. M. Raushel and H. M. Holden, Biochemistry, 1995, 34, 7973-7978.

19 C. J. Jackson, H.-K. Kim, P. D. Carr, J.-W. Liu and D. L. Ollis, Biochim. Biophys. Acta, 2005, 1752, 56-64.

20 C. J. Jackson, J.-L. Foo, H.-K. Kim, P. D. Carr, J.-W. Liu, G. Salem and D. L. Ollis, J. Mol. Biol., 2008, 375, 1189-1196.

21 V. E. Lewis, W. J. Donarski, J. R. Wild and F. M. Raushel, Biochemistry, 1988, 27, 1591-1597.

22 H. Shim and F. M. Raushel, Biochemistry, 2000, 39, 7357-7364.

23 M. Jarenmark, H. Carlsson and E. Nordlander, C. R. Chim., 2007, 10, 433-462.

24 R. Kramer and T. Gajda, Perspect. Bioinorg. Chem., 1999, 4, 209-240.

25 H. Carlsson, M. Haukka and E. Nordlander, Inorg. Chem., 2004, 43, $5681-5687$.

26 M. Jarenmark, S. Kappen, M. Haukka and E. Nordlander, Dalton Trans., 2008, 993-996.

27 A. K. Boudalis, R. E. Aston, S. J. Smith, R. E. Mirams, M. J. Riley, G. Schenk, A. G. Blackman, L. R. Hanton and L. R. Gahan, Dalton Trans., 2007, 5132-5139.

28 J. Chen, X. Wang, Y. Zhu, J. Lin, X. Yang, Y. Li, Y. Lu and Z. Guo, Inorg. Chem., 2005, 44, 3422-3430.

29 P. Karsten, A. Neves, A. J. Bortoluzzi, M. Lanznaster and V. Drago, Inorg. Chem., 2002, 41, 4624-4626.

30 M. Lanznaster, A. Neves, A. J. Bortoluzzi, V. V. E. Aires, B. Szpoganicz, H. Terenzi, P. C. Severino, J. M. Fuller, S. C. Drew, L. R. Gahan, G. R. Hanson, M. J. Riley and G. Schenk, JBIC, J. Biol. Inorg. Chem., 2005, 10, 319-332.

31 S. J. Smith, A. Casellato, K. S. Hadler, N. Mitic, M. J. Riley, A. J. Bortoluzzi, B. Szpoganicz, G. Schenk, A. Neves and L. R. Gahan, JBIC, J. Biol. Inorg. Chem., 2007, 12, 1207-1220.

32 J. K. Bashkin, Curr. Opin. Chem. Biol., 1999, 3, 752-758.

33 A. Neves, M. Lanznaster, A. J. Bortoluzzi, R. A. Peralta, A. Casellato, E. E. Castellano, P. Herrald, M. J. Riley and G. Schenk, J. Am. Chem. Soc., 2007, 129, 7486-7487.

34 A. Neves, M. A. de Brito, V. Drago, K. Griesar and W. Haase, Inorg. Chim. Acta, 1995, 237, 131-135.

35 G. Schenk, R. A. Peralta, S. C. Batista, A. J. Bortoluzzi, B. Szpoganicz, A. K. Dick, P. Herrald, G. R. Hanson, R. K. Szilagyi, M. J. Riley, L. R. Gahan and A. Neves, JBIC, J. Biol. Inorg. Chem., 2008, 13, 139-155.

36 L. L. Koh, J. O. Ranford, W. T. Robinson, J. O. Svensson, A. L. C. Tan and D. Wu, Inorg. Chem., 1996, 35, 6466-6472.

37 J. M. Botha, K. Umakoshi, Y. Sasaki and G. J. Lamprecht, Inorg. Chem., 1998, 37, 1609-1615.

38 R. T. Paine, Y.-C. Tan and X.-M. Gan, Inorg. Chem., 2001, 40, 70097013.

39 N. M. F. Carvalho, A. Horn Jr., R. B. Faria, A. J. Bortoluzzi, V. Drago and O. A. C. Antunes, Inorg. Chim. Acta, 2006, 359, 4250-4258.

40 A. M. W. Cargill Thompson, D. A. Bardwell, J. C. Jeffery and M. D. Ward, Inorg. Chim. Acta, 1998, 267, 239-247.

41 C. White, S. J. Thompson and P. M. Maitlis, J. Organomet. Chem., 1977, 134, 319-325.

42 S. Kitagawa, M. Kondo, S. Kawata, S. Wada, M. Maekawa and M. Munakata, Inorg. Chem., 1995, 34, 1455-1465.

43 U. Bossek, G. Haselhorst, S. Ross, K. Wieghardt and B. Nuber, J. Chem. Soc., Dalton Trans., 1994, 2041-2048.

44 N. G. Connelly, T. Einig, G. G. Herbosa, P. M. Hopkins, C. Mealli, A. G. Orpen, G. M. Rosair and F. Viguri, J. Chem. Soc., Dalton Trans., 1994, 2025-2039.

45 A. R. Sherman, in Pyridine, Encyclopedia of Reagents for Organic Synthesis, ed. L. A. Paquette, J. Wiley \& Sons, New York, 2004.
46 G. P. Mullen, E. H. Sepersu, L. J. Ferrin, L. A. Loeb and A. S. Midvan, J. Biol. Chem., 1990, 265, 14327.

47 I. H. Segel, Enzyme Kinetics: Behavior and Analysis of Rapid Equilibrium and Steady-State Enzyme Systems, Wiley-Interscience, New York, 1975.

48 J. Xia, Y. Shi, Y. Zhang, Q. Miao and W. Tang, Inorg. Chem., 2003, 42, $70-77$.

49 B. Bauer-Siebenlist, F. Meyer, E. Farkas, D. Vidovic, J. A. CuestaSeijo, R. Herbst-Irmer and H. Pritzkow, Inorg. Chem., 2004, 43, 41894202.

50 C. Bazzicalupi, A. Bencini, E. Berni, A. Bianchi, V. Fedi, V. Fusi, C. Giorgi, P. Paolettti and B. Valtancoli, Inorg. Chem., 1999, 38, 41154122.

51 A. Bencini, E. Berni, A. Bianchi, V. Fedi, C. Giorgi, P. Paolettti and B. Valtancoli, Inorg. Chem., 1999, 38, 6323-6325.

52 M. Arca, A. Bencini, E. Berni, C. Caltagrione, F. A. Devillanova, F. Isaia, A. Garau, C. Giorgi, V. Lippolis, A. Perra, L. Tei and B. Valtancoli, Inorg. Chem., 2003, 42, 6929-6939.

53 B. Bauer-Siebenlist, F. Meyer, E. Farkas, D. Vidovic and S. Dechert, Chem.-Eur. J., 2005, 11, 4349-4360.

54 E. Kimura, T. Shiota, T. Koike, M. Shiro and M. Kodama, J. Am. Chem. Soc., 1990, 112, 5805-5811.

55 T. Koike and E. Kimura, J. Am. Chem. Soc., 1991, 113, 8935-8941.

56 Y. Gultneh, A. R. Khan, D. Blaise, S. Chaudhry, B. Ahvazi, B. B. Marvey and R. J. Butcher, J. Inorg. Biochem., 1999, 75, 7-18.

57 M. Yashiro, H. Kaneiwa, K. Onaka and M. Komiyama, Dalton Trans., 2004, 605-610.

58 L. M. Berreau, Eur. J. Inorg. Chem., 2006, 273-283.

59 M. Livieri, F. Mancin, U. Tonellato and J. Chin, Chem. Commun., 2002, 2862-2863.

60 R. Mitra, M. W. Peters and M. J. Scott, Dalton Trans., 2007, 3924 3935.

61 N. V. Kaminskaia, C. He and S. J. Lippard, Inorg. Chem., 2000, 39, 3365-3373.

62 C. He and S. J. Lippard, J. Am. Chem. Soc., 2000, 122, 184-185.

63 C. R. Samples, T. Howard, F. M. Raushel and V. J. De Rose, Biochemistry, 2005, 44, 11005-11013.

64 K.-Y. Wong and J. Gao, Biochemistry, 2007, 46, 13352-13369.

65 G. Schenk, L. R. Gahan, L. E. Carrington, N. Mitic, M. Valizadeh, S. E. Hamilton, J. De Jersey and L. W. Guddat, Proc. Natl. Acad. Sci. U. S. A., 2005, 102, 273-278.

66 R. S. Cox, G. Schenk, N. Mitic, L. R. Gahan and A. C. Hengge, J. Am. Chem. Soc., 2007, 129, 9550-9551.

67 D. W. Christianson, Acc. Chem. Res., 2005, 38, 191-201.

68 S. Ciurli, Urease: Recent Insights on the Role of Nickel, Metal Ions in Life Sciences, ed. A. Sigel, H. Sigel and R. Sigel, John Wiley \& Sons, Chichester, 2007.

69 S. Ciurli, S. Benini, W. R. Rypniewski, K. S. Wilson, S. Miletti and S. Mangani, Coord. Chem. Rev., 1999, 190-192, 331-355.

70 C. R. Samples, F. M. Raushel and V. J. DeRose, Biochemistry, 2007, 46, 3435-3442.

71 X. Wang, R. Y. N. Ho, A. K. Whiting and L. Que Jr., J. Am. Chem. Soc., 1999, 121, 9235-9236.

72 M. B. Twitchett and A. G. Sykes, Eur. J. Inorg. Chem., 1999, 2105-2115.

73 B. K. Takasaki and J. Chin, J. Am. Chem. Soc., 1995, 117, 8582-8585.

74 G. Feng, D. Natale, R. Prabaharan, J. C. Mareque-Rivas and N. H. Williams, Angew. Chem., Int. Ed., 2006, 45, 7056-7059.

$75 \mathrm{M}$. Monroe, Molecular weight calculator for Windows 9x/ME/ NT/00/XP, version 6.35, http://www.alchemistmatt. com.

76 A. Altomare, M. C. Burla, M. Camalli, G. L. Cascarano, C. Giacovazzo, A. Guagliardi, A. G. G. Moliterni, G. Polidori and R. Spagna, J. Appl. Crystallogr., 1999, 32, 115.

77 G. M. Sheldrick, SHELXL-97, Program for refinement of crystal structures, University of Göttingen, Germany, 1997.

78 L. J. Farrugia, J. Appl. Crystallogr., 1999, 32, 837-838.

79 L. J. Farrugia, J. Appl. Crystallogr., 1999, 30, 565.

80 P. Gans, A. Sabatini and A. Vacca, J. Chem. Soc., Dalton Trans., 1985, $1195-1200$. 